\title{
Rakka Valisi Hamalızâde Ahmed Paşa'nın Muhallefatı (1745)
}

\author{
Bekir Gökpınar*
}

(ORCID ID: 0000-0003-1017-6037)

\section{Makale Gönderim Tarihi}

24.02.2020

\author{
Makale Kabul Tarihi
}

06.03.2020

\section{Özet}

Hamalızâde Ahmed Paşa, 1731-1745 yılları arasında muhtelif aralıklarla Rakka valisi olarak görev yapmıştır. Burada görev yaptığı yıllarda çok geniş bir sınır boyunca Osmanlı-iran mücadelesi devam etmekteydi. Zaman zaman İran güçleri tarafından işgale uğrayan şehirlerin kurtarılması için bölgesel seferler düzenlenmişti. Bunun için sınır bölgelerine yakın vilayetlerden askeri sevkiyatlar yapılmaktaydı. Bu kapsamda Ahmed Paşa daha çok Bağdat, Musul, Kerkük, Erzurum ve Kars gibi şehirlerde görev yapmıştır. Rakka valiliği sırasında kendisi ve mahiyetinde bulunan kimselerin ahaliye karşı çok sert uygulamalar yaptıkları, bundan dolayı da hayatının son döneminde görev yeri olan Ruha'ya dönemediği bilinmektedir. Devlete karşı yaptığı yararlı hizmetlerin aksine halk üzerindeki baskı ve zulmü dolayısıyle görevden alınmış ve Rodos adasına sürgün edilmesine karar verilmiştir. Ancak etrafında çok kalabalık gruplar olduğu halde Kilis'ten hareke edip Mercidabık'a vardığı sırada vefat etmiştir. Ahmed Paşa vefatı ile birlikte hatırı sayılır miktarda muhallefatı olduğu tespit edilmişti. Öncelikle Mercidabık'ta yanında bulunan, sonra Ruha'da bulunan eşya, emval ve hayvanları kaydedilip satılmıştır.

Hamalızâde Ahmed Paşa'nın Rakka valiliği, doğu sınırında yaptığı faaliyetler ve nihayet vefatı ile birlikte muhallefatının zabt edilerek tespiti ve satış süreci başta Osmanlı Arşivindeki defter ve belgeler yanında dönemin kroniklerinden istifade edilerek incelenmiştir.

Anahtar Kelimeler: Hamalızâde Ahmed Paşa, Rakka, muhallefat, Ruha, Halep.

*Dr., bgokpinar@gmail.com.

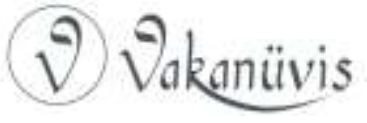




\section{Muhallefat of Raqqa Governor Hamalızâde Ahmed Pasha (1745)}

\section{Abstract}

Hamalıâde Ahmed Pasha served as the governor of Raqqa at several intervals between 1731 and 1745 . During the years he served there, the Ottoman-Iran struggle continued along a wide border. From time to time, regional campaigns were organized to save the cities occupied by Iranian forces. For this reason, military shipments were made from the provinces close to the border regions. In this context, Ahmed Pasha mostly worked in cities such as Baghdad, Mosul, Kirkuk, Erzurum and Kars. It is known that during the Raqqah Governorate, he and his attendants performed very severe implementations against the people, and therefore could not return to Ruha, which was his post in the last period of his life. Although he had useful services for state, he was dismissed from his post because of his oppression and persecution against local community, and it was decided to be exiled to Rhodes Island. However, although there were very crowded groups around him, he died while he was going to Marj Dabiq from Kilis. It was determined that he had a considerable amount of inheritance (muhallefat) with the death of Ahmed Pasha. Primarily the goods, assets and animals found in Marj Dabiq and then in Ruha were listed and sold.

With Hamalıâde Ahmed Pasha's governorship, activities on the eastern border, and finally his death, detection of his inheritance by recording and sales process were examined by taking advantage of the chronicles of the period, along with the registeries and documents in the Ottoman State Archives.

Keywords: Hamalızâde Ahmed Pasha, Raqqa, muhallefat, Ruha, Aleppo.

\section{Giriş}

Rakka Valisi Ahmed Paşa, Osmanlı bürokrasisi içinde ilk görev yeri olarak Bağdat Valisi Ahmed Paşa'nın kethüdası olarak karşımıza çıkmaktadır. 1731 yılında İran'ın eline geçen Kirmanşah ve Hemedan seferine Bağdat Valisi Ahmed Paşa serasker tayin edilmiştir. Ahmed Paşa, Kirmanşah yakınlarında Tahmasp güçleri ile yapılan savaşta galip gelmiş ve önemli miktarda mühimmat ele geçirilmiştir. Bu savaş sonucunda Kirmanşah'ın feth edilirken Hemedan kendiğilinden teslim olmuştu. Bu seferde padişah I. Mahmud, Bağdat Valisi Ahmed Paşa'yı 
hatt-ı hümayun, sorguç ve hilat ile taltif etmiştir. ${ }^{1}$ Ayrıca söz konusu sefer sırasında seraskerin kethüdası olarak bulunan Ahmed Paşa'ya da üç tuğ ile birlikte vezirlik insan olunmuştur. Ahmed Paşa, bundan sonra "Hamalıoğlu" diye şöhreti yayılmıştır. Bir müddet sonra da beylerbeyi ünvanı almıştır. ${ }^{2}$

Bağdad Valisi Ahmed Paşa tarafından kethüdası Ahmed Paşa'nın bu seferde olan gayretleri padişaha arz edilmiştir. Bunun üzerine kethüda Ahmed Paşa'ya vezirlik yanında 3.000 nefer ile birlikte Hemedan kalesi muhafazasına gitmesi şartıyla Rakka eyaleti valiliğine tayin edilmiştir (Ekim 1731). ${ }^{3} 1145$ (1732-33) yılında Basra Valisi Abdurrahman Paşa'nın vefatı üzerine bu defa buraya vali olarak görevlendirilmiş ancak bu görevde kısa süre kalabilmiş, 1146 (1733-34)' te azl edilmiştir. ${ }^{4}$

1147 (1734-35) yılında tekrar Rakka valisi olmuş, 1735-36 yılındaki İran seferlerinde seraskerin maiyyetinde memur olarak görev yapmıştır. İran seferi sırasında Nadir Han ile Arpaçay yakınlarında Bogaverd civarında yapılan savaşta Şark Seraskeri Abdullah Paşa şehit düşmüştür. Bunun üzerine ordu üzerine yeni serasker tayin olununcaya kadar serasker vekili olarak tayin edilmiştir. Osmanlı ordusunun Kars civarına çekilmesi ile birlikte burada da seraskerlik görevini sürdürmüştür. ${ }^{5}$

\footnotetext{
1 Şemdâni-zâde Fındıkıılı Süleyman Efendi Târihi Mür'it-Tevârih, I, Haz. Münir Aktepe, iü Edebiyat Fakültesi Yayınları, İstanbul 1976, s. 25.

${ }^{2}$ Mür'it-Tevârih, I, s. 25; Mehmed Süreyya, Sicilli Osmanî, Yay. Haz. Nuri Akbayar, C.I, Tarih Vakfı Yurt Yayınları, İstanbul 1996, s. 211; Kethüda, Osmanlı Devlet teşkilatı içinde XV.yüzyıldan itibaren devlet işlerii yürütmekte olan yardımcı anlamında kullanılmaktadır. XVI. yüzyıldan itibaren ise beylerbeyi ve valilerin yanında birden fazla kethüda bulunurdu. Seçimi tamamen valilere ait olup, işlerinde başarılı olanlar daha üst memuriyetlere tayin edilirdi. Mehmet Canatar, "Kethüdâ", DiA, C. 25, Ankara 2002, s. 332-333.

3 "Vezîrim Ahmed Paşa edâmallahü te'alâ iclâlehûnün iltimâsı üzere avâtıf-ı aliyye-i mülûkânemden rütbe-i vâlâ-yı vezâret ile hasedetü'l-vüzerâ olan Rakka eyâleti sana tevcîh ve ihsânım...", Mehmed Günay, Ruha Valisi Hamalızâde Ahmed Paşa'nın Vekâyi'i (1156-1158), Marmara Üniversitesi Türkiyat Araştırmaları Enstitüsü, Basılmamış Yüksek Lisans Tezi, İstanbul 1994, s. 78; Vak'anüvis Subhî Mehmed Efendi, Subhî Tarihi, Sâmi ve Şâkir Tarihleriyle Birlikte 1730-1744, (Inceleme ve Karşılaştırmalı Metin), Haz. Mesut Aydıner, Kitabevi, İstanbul 2007, s. 115.

${ }^{4}$ Subhî Tarihi, s. 173-174; Mehmed Süreyya, Sicilli Osmanî, C.I, s. 211.

5 "Halâ Rakka Vâlisi olan Vezîr Ahmed Paşa'ya hüküm ki; Abdullah Paşa'nın vefatından sonra ta'yîn olacak ser-askerim o câniblere varıncaya dek tîz elden sen ki vezîr-i müşârun-ileyhsin. Senin serasker vekîli olman fermânım olmaktan nâşî sen ber-vech-i
}

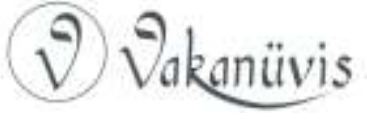


Ancak ordu üzerine yeni seraskerin tayini ile birlikte yanında memurluğa devam etmiş, 11 Nisan 1736 tarihinde Rakka'ya dönme talebinde bulunmuştur. Ahmed Paşa'nın bu talebi uygun görülerek esas görev mahalli olan Rakka'ya dönmüştür. ${ }^{6}$ Nitekim 18 Ekim 1736 tarihinde Rakka eyaleti valilik makamında olduğu, 1737 yılı başından itibaren ise "mâlikâne"7 usulü ile aynı görevin kendisine tevcih edildiği görülmektedir. Ahmed Paşa, Rakka eyaletini "mâlikâne" usulü ile 1738 ve 1739 yıllarında da tasarruf etmeye devam etmiştir. ${ }^{8}$

1738 yılında Aydın'da babasının mal varlığının devlet tarafından el koyulması, kız kardeşinin Osmanlı sarayına gönderilmesi ve İzmir'in ticari cazibesinin etkisi ile ${ }^{9}$ ortaya çıkan ve civar bölgelerde isyan halinde olan Sarıbeyoğlu eşkiyası üzerine Yekçeşm Ahmed Paşa, Hamalızâde Ahmed Paşa ile birlikte gönderilmiştir. Honaz kalesini alıp yerleşmiş olan Sarıbeyoğlu, Ahmed Paşa'lar tarafından kuşatılmıştır. Ancak Sarıbeyoğlu yanındaki adamalarla birlikte bir gece aniden çıkıp kaleyi kuşatan

muharrer serasker vekili nasb...", ilker Külbilge, 141 Numaralı Mühimme Defteri (H. 1148), Ege Üniversitesi Sosyal Bilimler Enstitüsü Basılmamış Yüksek Lisans Tezi, İzmir 2002, s. 162-163; İsmail Hakkı Uzunçarşılı, Osmanlı Tarihi, IV/I, Ankara 1978, s. 229-230; Mehmed Süreyya, Sicilli Osmanî, C.I, s. 211.

6 “...lâkin za'f hâline binâ'en mansıbına avd ve rica'ata ordu-yu hümâyûnum tarafından me'zûn olmakla...", Külbilge, a.g.t, s. 296-297.

7 Malikane usulü, Osmanlı'da ilk defa 1695 yılında uygulanmaya başlamıştır. Malikane; iltizam sisteminin aksine mukataaların taliplerine "kayd-ı hayat" yani ömür boyu verilmesidir. Bu sistem uzun süren savaşlar sebebiyle maliyenin nakit sıkıntısını çözmek amacıyla uygulamaya başlanmıştır. Bazı eyaletler vali, muhassıl, defterdar ve voyvodaların iltizamlarında bulunmakta, Rakka da bunlardan biriydi. Malikane sisteminde devlete olan ödemeler yıllık 4 taksit halinde yapılırdı. Geniş bilgi için bkz. Ahmet Tabakoğlu, Gerileme Dönemine Girerken Osmanlı Maliyesi, Dergah Yayınları, İstanbul 1985, s. 129-135; Erol Özvar, Osmanlı Maliyesinde Malikâne Uygulaması, Kitabevi, İstanbul 2003, s. 19-26; Baki Çakır, Osmanlı Mukataa Sistemi (XVI-XVIII. Yüzyıl), Kitabevi, İstanbul 2003, s. 154-169.

8 Ruus Defteri kayıtlarında 1736-1739 yılları arasında Rakka Valisi Kethüda Ahmed Paşa olarak geçmektedir. Bağdat Valisi Ahmed Paşa'nın kethüdalığını yapmasından dolayı bu isimle anıldığı tahmin edilmektedir. Orhan Kılıç, 18. Yüzyılın ilk Yarısında Osmanlı Devleti'nin Idari Taksimatı, Eyalet ve Sancak Tevcihatı, Ceren Matbaacılık, Elazığ 1997, s. 156.

${ }^{9}$ Hakan Karagöz, "Bir Alman Kaynağının İzlenimlerine Göre Sarıbeyoğlu İsyanının Batı Anadolu'daki Etkileri”, Süleyman Demirel Üniversitesi Fen-Edebiyat Fakültesi Sosyal Bilimler Dergisi, Kemal Göde Armağan Sayısı, Isparta 2013, s. 197-198.

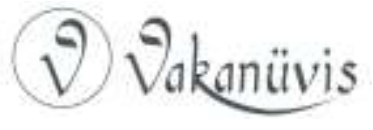


orduyu mağlup etmiş, eşyalarını da zabt etmiştir. ${ }^{10}$ Ertesi yıl Sarıbeyoğlu eşkiyası üzerine Hamalızâde Ahmed Paşa serasker olarak tayin olunmuştur. Bu defa Sarıbeyoğlu, mukavemet edemeyerek firar etmiş, Sarayköy yakınlarında Alaşehirli Ömer Ağa arkasından yetişerek birkaç adamıyla birlikte yakalayıp başını kesmiş ve böylelikle bu gaile ortadan kaldırılmıştır (1739). ${ }^{11}$

Rakka Valisi Ahmed Paşa, tekrar Kars seraskerliğine tayin edilmiş, bu görevi ifa için 25 Şubat 1743'te Erzurum'a ulaşmıştır. Burada bir müddet kaldıktan sonra Erzurum'da bulunan askerle birlikte 19 Aralık 1743 tarihinde Kars'a intikal etmiştir. ${ }^{12}$ Rakka Valisi Hamalızâde Ahmed Paşa 1744 yılında Kars seraskeri iken bir müddeten beri devam eden hastalığı aniden nüks ederek ilerlemiş, hemen hemen bütün vücuduna yayılmış ve kronik hale gelmiştir. Bu durum paşanın emrindeki askeri sevk ve idare konusunda zaafiyetine sebep olmuş, bundan dolayı da bu görevinden azl edilerek Erzurum muhafazasına memur olmuştur. Kars sınır mıntıkası olduğu için burada çok miktarda asker bulunmakta olup, bunların maişeti ve sevki konusunun mühim olduğu bilinmektedir. Bunun üzerine yerine Sayda eyaletinin eski mutasarrıfı eski sadrazam Ahmed Paşa tayin olunmuştur (20 Muharrem 1157/5 Mart 1744). ${ }^{13}$

Bir müddetten beri "mâlikâne" yoluyla Rakka valisi olan Hamalızâde Ahmed Paşa, Erzurum ve Kars tarafındaki görevlerinden ayrılarak 1 Mart 1745 'te esas görev mahalline dönmek üzere Erzurum'dan hareket ederek Arapkir üzerinden yola çıkmıştı. Artık hem hastalığının ve yaşının ilerlemesi hem de esas görev mahalli olmasından dolayı bundan sonra Rakka'ya dönerek burada ikamet etme niyetinde idi. Ancak Ahmed Paşa'nın Rakka'ya dönüş haberinin alınması üzerine daha yolda iken

\footnotetext{
${ }^{10}$ Mür'it-Tevârih, I, s. 85.

${ }^{11}$ Mür'it-Tevârih, I, s. 89; Subhî Târihi, s. 529; Mehmet Yaşar Ertaş, "XVIII. Yüzyılda Bir Osmanlı Eşkıyası: Sarıbeyoğlu Mustafa", Uluslararası Denizli ve Çevresi Tarih ve Kültür Sempozyumu, Bildiriler, (6-8 Eylül 2006), C. I, Denizli 2007, s. 409-411.

12 Günay, a.g.t, s. 5.

13 "Cânib-i mezbûr seraskeri olan Rakka vâlisi vezîr Ahmed Paşa'nın bir müddetten beri mizâcına tarî olan ilel ve eskâm idâre-i umûr-ı ser-askerîde adem-i kudret ve liyâkatına mûcib...", AE. SMHD. nr. 21171; Mür'it-Tevârih, I, s. 112; İzzî Süleyman Efeni, İzzî Tarihi (Osmanlı Tarihi, 1157-1165/1744-1752), Haz. Ziya Yılmazer, Türkiye Yazma Eserler Kurumu Başkanlığı Yayınları, İstanbul 2019, s. 21; Mehmed Süreyya, Sicilli Osmanî, C.ı, s. 211.
}

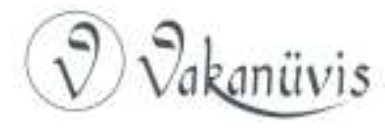


Ruha'da bazı kargaşalıklar çıkmaya başlamıştır. Aslında bunlar geçmişte yaptığı haksız uygulamalara karşı ahalinin tepkisi idi. ${ }^{14}$ Hamalızâde Ahmed Paşa'nın ahaliye zulm ettiği, zorla mal ve eşyalarını aldığı, insanlara çok ızdırap çektirdiği, rüşvet aldığı ve merhametsiz bir cibilliyete sahip olduğu bilinmekteydi. Nitekim Rakka'ya daha gelmeden etrafında topladığı 10 bin kadar adamı ile ahaliden zorla mal ve eşya almaya başlamıştı. Damadı Süleyman da Ruha mütesellimi olarak "salyâne" tarikiyle üç yılda ahaliden 29 bin kese akçe fazla parayı zorla toplamıştı. Rakka ahalisi Ahmed Paşa'nın zulmünden korkarak toplanıp onun öncelikle şehre girmesine mani olmuşlardır. Akabinden Ahmed Paşa'nın zor kullanarak ve rüşvet olarak aldığı paraların hüccetleri ile birlikte ahaliden birkaç kişiyi bu durumu arz etmek üzere İstanbul'a göndermişlerdi. İstanbul'da Ahmed Paşa'nın ahaliye yaptığı haksız tavır ve uygulamaları izah etmişler, artık ahali ve fukaranın buna tahammülleri kalmadığını belirtmişlerdir. Artık buradaki ahaliyi yeniden cesaretlendirip güçlendirmek için başka bir vali tayin edilmesini talep etmişlerdir. Devlet ahalinin talebini dikkate alarak Rumeli valisi olup, bazı sefer işleri için Sivas'ta bulunan Pirî Mustafa Paşa'yı Rakka'ya vali tayin etmiştir. Ahmed Paşa'nın yaptığı zulümler sebebiyle tuğlarının alınarak azl edilip tedip amacıyla Rodos'a sürgün edilmesi hususunda Mirahur-ı Evvel şehriyari Hasan Paşazade Abdullah Bey vasıtasıyla ferman gönderilmiştir (24 Safer 1157/28 Mart 1745). ${ }^{15}$

Ahmed Paşa'nın Rakka'ya dönmesi uygun görülmeyerek görevinden azl edilmiş ve etrafında toplanan kalabalıkla birlikte Halep tarafından geçmekte iken mübaşir kendisine söz konusu hatt-ı hümayunu tebliğ etmiştir. Ahmed Paşa, Mirahur-ı Evveli bir müddet yanında gezdirmiş, kendisine tebliğ edilen emri her ne kadar itaat eder gibi gözükse de yanındaki kalabalık adamlarıyla birlikte Halep'e geçmiş, oradan da Kilis üzerinden Mercidâbık'a ulaşmıştır. Özellikle yanındaki leventler paşanın yanından ayrılmayarak "biz paşamızı vermeyiz" diyerek mübaşire karşı koymuşlardır. Ahmed Paşa, bunun üzerine mülayim ve mutedil hareket ederek olayı büyütmemeye çalışmış, diğer taraftan "Levendâtın hâli

\footnotetext{
${ }^{14}$ Günay, a.g.t, s. 13-17.

15 "Bir müddetten berü Rakka vâlisi olup nice mezâlim ve te'addiyâtı bu def'a ahâlî taraflarından arz I i'lâm ve ve cevr ve ezâsının re'âyâ ve berâyâ üzerlerinden ref' ve izâlesi istirhâm olunduğuna binâ'en...", C.DH. nr. 7698; Günay, a.g.t, s. 20-22; Izzî Tarihi, s. 98100.
}

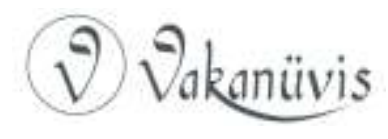


böyledir. Bunlara adâb-ı münâzara üzere kelâm-ı ifhâm olunmaz" diyerek de mübaşiri korkutarak uzaklaştırmaya çalışmış, ancak kendisi de itaat dairesine girmeyerek bildiği yolda ilerlemeye devam etmiştir. Bu durumun İstanbul'a arz edilmesi üzerine padişah "Çok görmüşüz zevâlini gaddâr olanların" diyerek paşanın artık ortadan kaldııılması gerektiğini ifade etmiştir. Mübaşir yeni fermanı kendisine tebliğ için yola çıkmış ve bu arada Hamalızâde Ahmed Paşa'da ordusu ile birlikte Halep yakınlarında bulunan Mercidabık'ta iken eceli ile vefat etmiştir (20 Cemâziyelevvel 1158/20 Haziran 1745). ${ }^{16}$ Cenazesi buradan alınarak Halep'e götürülmüş ve Şeyh Ebu Bekir Vefâi türbesine defn edilmiştir. ${ }^{17}$

\section{Rakka Valisi Ahmed Paşa'nın Muhallefatının Müsaderesi}

Osmanlı Devletin'de XV. yüzyıldan başlayarak XIX. yüzyıla kadar sadrazamlar başta olmak üzere katl edilen, azl edilen veya eceliyle ölen devlet ricalinin muhallefatı miri için müsadere edilmiştir. Böylelikle kul sistemi içinden gelen devlet ricali ölümüne kadar zengin bir hayat yaşamakta ve devletin bütün imkanlarından faydalanmakta ancak öldükleri zaman bütün emval, eşya ve servetine el konularak imparatorluk içinde herhangi bir aristokratik ve feodal oluşumlara müsaade edilmemiştir. ${ }^{18}$ Müsadere işlemleri için merkezden bir mübaşir gönderilir, o mahallin kadısının da işlemleri mübaşir ile birlikte yapması istenirdi. Ölen kişinin muhallefatı önce zabt edilir, sonra sayım işlemlerine başlanırdı. Akabinden müsadereye konu emval, emlak ve eşyanın defteri hazırlanırdı. Muhallefatın kimi mahallinde müzayede usulü ile satılır, kimi İstanbul'a gönderilirdi. Mübaşirden başka dellâl ve katip de bulunurdu. Bunların temel görevi muhallefatı noksansız olarak sayım yaparak yazmak ve satış işlemlerini yapmaktır. ${ }^{19}$ Bu minval üzere Rakka Valisi Hamalızâde Ahmed Paşa'nın azl edilip Rodos'a sürgün kararı ile birlikte bunu tebliğ ve aynı zamanda eşya, emlak ve hayvanlarının zabtı için Mirahur-ı Evvel Abdullah Bey tayin edilmişti. Bu esnada Ahmed

\footnotetext{
${ }^{16}$ Ahmed Paşa'nın ölümüyle ilgili mirahurun tabip vasıtasıyla zehir verdiği rivayeti de yer almaktadır. Mür'it-Tevârih, I, s. 116; İzzî Tarihi, s. 101-102; Mehmed Süreyya, Sicilli Osmanî, C.I, s. 211.

17 Günay, a.g.t., s. 33.

18 Mehmet Ali Ünal, “Osmanlı İmparatorluğunda Müsadere”, Türk Dünyası Araştırmaları Dergisi, S. 49 (Ağustos 1987), s. 100-101.

${ }^{19}$ Cahit Telci, "Osmanlı Devletinde 18. Yüzyılda Muhallefat ve Müsâdere Süreci", Tarih incelemeleri Dergisi, C. XXII, S. 2 (Aralık 2007), s. 150-153.
}

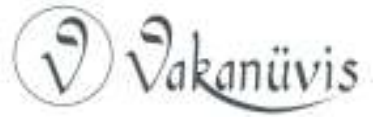


Paşa Kilis'ten hareket ederek Mercidâbık'a gelmiş ve burada ordusu ile birlikte bir müddet ikamet etmek arzusunda idi. Ancak Ahmed Paşa 25 Haziran 1745 (25 Cemâziyelevvel 1158) tarihinde burada eceli ile vefat etmişti. Bu defa azl ile değil vefat ile birlikte Ahmed Paşa'nın muhallefatının müsadere süreci başlamıştır. Muhallefatının müsaderesi iki adımda gerçeleştirilmiştir. İlk etapta Mirahur-ı Evvel Abdullah Bey, Ahmed Paşa'nın ordusu yanında bulunan eşya, emlak ve hayvanlarını müsadere edip zabt etmiştir. Söz konusu muhallefata konu olan eşya öncelikle Halep'e nakl edilmiş, burada icab edenler satılmış bir kısmı ise satılmayarak bırakılmıştı. ${ }^{20}$ Daha sonra ise Rakka eyaletinin Paşa sancağı olan Ruha'da olan muhallefatı müsadere edilmiştir. Nitekim Ruha'da bulunan muhallefatı ise halefi olan Rakka Valisi Mustafa Paşa'nın nezaretinde müsadere edilip sayımı yapılmış ve defteri hazırlanmıştır. Bilahare bunlar Dergah-ı Ali Kapıcıbaşılarından Hasan Ağa tarafından Halep'e nakl edilmiş ve burada Mirahur-ı Evvel Abdullah Efendi'ye teslim edilmiştir. ${ }^{21}$

Ahmed Paşa'nın muhallefatının satışı konusunda Mirahur-ı Evvel Abdullah Bey'e yetki verilmişti. Bununla birlikte satışla ilgili bazı önemli hususlara dikkat edilmesi gerektiği hatırlatılmıştı. Öncelikle başta emlak ve akarı olmak üzere emval ve eşyasının Ruha'da değeri üzerinden satılması konusunda tenbihat yapılmıştır. Çünkü muhallefatın değerinde satılmaması durumunda beytülmalın zararına sebep olanacaktı. Ruha'da satılamayanların ise Halep'e gönderilerek burada "müzâyede" usülü ile satılması istenmişti. Zira Halep öteden beri ulu bir şehir olmakla birlikte tüccar ve servet sahiplerinin çok olduğu bir mahal olup muhallefatın rayici üzerinden satılması ihtimali kuvvetli idi. Ancak Ruha ve Halep'te rayic değerini bulamayan emval ve eşyanın ise İstanbul'a gönderilerek burada satışının yapılması emredilmişti. Böylelikle Abdullah Paşa'nın muhallefatının alelade satışına izin verilmemiş, piyasa fiyatı üzerinden satılması konusunda hassasiyet gösterilmiştir. ${ }^{22}$

20 "Kilis'den hareket ve Merc-i dâbık nâm mahalle gelüp ordu ile bir müddet ikâmet ve Mâh-ı Cemâziye'l-Evvel'in yirmi beşinci günü hulûl-ı ecel-i müsemmâsıyla âzim-i dâr-ı bekâ olduğundan...", D.BŞM.d. nr. 2838, s. 2 (1 Receb 1158/30 Temmuz 1745); AE. SMHD-I. nr. 926.

${ }^{21}$ D.BŞM.MHF.d. nr. 12567, s. 2 (20 Şaban 1158/17 Eylül 1745).

22 "Haleb sevâd-ı a'zâm ve bâzergân ve tüccâr ve erbâb-ı servet vesâ'ir yatağı bir mahal olduğundan...", AE. SMHD-I. nr. 10683 (20 Cemaziye'l-âhir 1158/20 Temmuz 1745); "...

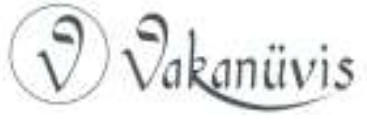




\section{Hamalızâde Ahmed Paşa'nın Muhallefatı}

Muhallefat ölen veya öldürülen kişilerin geride bıraktıkları her türlü emval, eşya ve paralarıdır. Bu kimi zaman tereke veya terîke olarak da kullanılmaktadır. Sözlükte de "geriye kalan, geride bırakılan" anlamındadır. ${ }^{23}$ Ahmed Paşa'nın muhallefatı ile ilgili Osmanlı Arşivinde iki defter bulunmaktadır. Bunlar; Başmuhasebe Kalemi Defterleri tasnifinde yer alan 2838 ve yine Başmuhasebe Kalemi Muhallefat Defterleri tasnifinde yer alan 12567 numaralı defterlerdir. 2838 numaralı defterde Ahmed Paşa'nın Mercidabık'ta vefatı sırasında yanında bulunan emval, eşya ve hayvanları, 12567 numaralı defterde ise Ruha'da bulunan emval, eşya, akarı ve hayvanları kaydedilmiştir. Zira Ahmed Paşa'nın Mercidabık'ta ordu yanında ve Ruha'da emlak, eşya, akarı ve hayvanları bulunmaktaydı. Bu nedenle her iki mahalde ayrı ayrı zabt, tahrir ve satış işlemleri yapılmıştır. Ahmed Paşa'nın Mercidabık'da ordusu yanında iken müsadere edilen muhallefatından 443.550 kuruş 5 akçe gelir elde edilmiş, bu meblağdan 352.595 kuruş muhtelif yerlere sarf edilmiş ve 90.955 kuruş 5 akçe hazineye kalmıştır. Ruha'da bulunan muhallefatın satışından ise 220.132 kuruş gelir elde edilmiş ve 210.033 kuruş muhtelif kalemlere masraf yapılmış, 10.099 kuruş ise hazineye gönderilmiştir. Böylelikle Ahmed Paşa'nın muhallefatının tamamının satışıla 663.682 kuruş 5 akçe gelir elde edilmiş ve bunun \% 85'i olan 562.628 kuruşu muhtelif masraflar için harcanmış, \% 15'ine tekabül eden 101.054 kuruş 5 akçe ise hazineye kalmıştır.

\subsection{Mercidabık'da müsadere edilen muhallefatı}

Hamalızâde Ahmed Paşa, Mercidabık'da kalabalık kapı halkı ile birlike bulunduğu sırada vefat ettiğinden Mirahur-ı Evvel Abdullah Bey tarafından zabt olunup tahrir edildikten sonra satılmak üzere Halep'e nakl olunan muhallefatı önemli bir yekün teşkil etmektedir. Ahmed Paşa'nın ordusu yanında bulunan muhallefatı 2838 numaralı

zikr olunan emlâk ve akardan Ruha'da ve ba'dehû Haleb'de müzâyede olunup eğer bahâları değerine bâliğ olmaz ise Âsitane-i Sa'adet'te fürûht olunmaları münâsib idiğün...", AE. SMHD-I. nr. 14288, (26 Cemâziye'l-âhir 1158/26 Temmuz 1745).

23 Tahsin Özcan, "Muhallefat", DiA, C. 35, Türkiye Diyanet Vakfı, İstanbul 2005, s. 406; Mehmet Zeki Pakalın, Osmanlı Tarih Deyimleri ve Terimleri Sözlüğü, C.ıl, Milli Eğitim Basımevi, İstanbul 1983, s. 564.

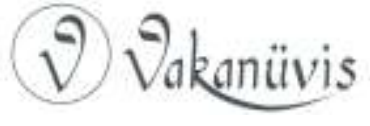


Başmuhasebe Defterinde, ordu yanında 621 kalem, Antep'te Battal Ağa'ya emanet edilen 82 kalem, Damadı Süleyman'ın yanında 33 kalem ve hazinedarı Selim'in yanında 72 kalem olmak üzre 808 kalem olarak listelenmiştir. Bazı eşyaların bir kısmı gruplar halinde de verilmiştir. Listeye göz attığımızda muhallefatın yük ve binek hayvanları ve bunlara ait binit takımları, silahlar, ev ve mutfak eşyaları, kumaşlar, giyim kuşam eşyası, kitaplar ve kölelerden oluştuğu görülmektedir.

Yük ve binek hayvanlarından atlarda kullanılan binit takımları temelde örtü olarak kesme ve haşe, binmek için eyer, raht, başlık, reşme, üzengi ve silah olarak da topuz ve gaddareden oluşmaktadır. ${ }^{24}$ Ahmed Paşa'nın yük ve binek hayvanları takımları arasında çok sayıda reşme ${ }^{25}$ ile birlikte kemer takımının mevcudiyeti dikkati çekmektedir. Bunların çoğunluğunu da gümüşten imal edilmiş büyük takımlar oluşturmakta, bir miktar küçük ve ince gümüş takımlar da mecuttur. Hayvanın eğeri üzerine örtülen kesme ${ }^{26}$ ve haşelerin ${ }^{27}$ çok çeşitleri vardır. Bunlar yeşil, kırmızı, laciverd kadifeli olduğu gibi kırmızı, siyah, mor, beyaz kumaşlar üzerinde gümüş kabaralı "müsta'mel" kesmeler olup, çoğunluğu işlemelidir. Yine bunlardan bir kısımı eski olduğuğu gibi Leh işi, Şam ve i̇stanbul menşeli "dibâ"28 denilen ipek kumaştan yapılmıştır. Yine eğer ile at sırtı arasına konulan ve gümüşten imal edilmiş "haşe" denilen örtü de önemli sayıda mevcuttur. Binek hayvanları için mevcut olan üzengilerin çoğunluğu da gümüşten yapılmıştır. Binek hayvanları takımları arasında yer alan gaddâre (pala) ve topuzların da çoğunluğu gümüşten yapılmıştır. Bu gaddâreler içinde padişah, sadrazam ve vali gibi önemli devlet adamlarının atlarını

\footnotetext{
${ }^{24}$ Emine Dingeç, "18. Yüzyılın İkinci Yarısında Saray Atlarının Binit Takımları", Uludağ Üniversitesi Sosyal Bilimler Dergisi, Yıl: 12, Sayı: 20 (2011/1), s. 5.

25 Reşme; atın alını ve burnu üzerine sallandırılan, üstünde gümüş veya altın yaldızlı süslemeler takılmış zincir. İlhan Ayverdi, Misalli Büyük Türkçe Sözlük, C. 3, Kubbealtı Neşriyat, İstanbul 2006, s. 2578.

${ }^{26}$ At eğerlerinin üstüne örtülen örtüdür. Pakalın, a.g.e, C.II, s. 249.

27 Haşe ve gâşiye aynı anlamdadır. Sırma şeritli ve sahibinin servet derecesine göre süslemeli eyer örtüsü. Mehmet Ali Ünal, Osmanlı Tarih Sözlüğ̈̈, Paradigma Yayınları, İstanbul 2011, s. 262.

28 Çiçek nakışları ile dokunmuş çok kıymetli ipekli bir kumaş türüdür. Bazen çiçekleri ipekleri arasına altın tellerde de yerleştirilirdi. Acem, Frengi, Venedik dibası gibi çok çeşitleri vardı. Reşat Ekrem Koçu, Türk Giyim, Kuşam ve Süslenme Sözlüğü, Sümerbank Kültür Yayınları, Ankara 1969, s. 89.
}

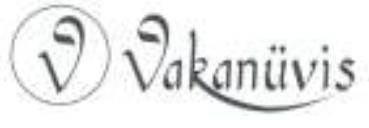


koruyan görevlilere ait gaddâreler de olup, tamamı kemerle birlikte gümüşten yapılmıştır.

Ev eşyaları ve mutfak malzemeleri muhallefat içinde 239 kalem olarak yer almaktadır. Bunlar arasında büyük ve küçük çok sayıda tepsi, fincan, şamdanlar, şamdan sofraları, ibrikler, leğenler, tütsülük, kılabdân (tel karşımı ip), sürahiler, su tasları, matara, nargile takımları, tuzluklar, çok çeşitli kaşık takımları önemli yer tutmaktadır. Bunların önemli kısmı bakır, porselen ve gümüşten yaplmış olup az miktarda altın eşya da mevcuttur. Nitekim 6 'sı gümüş, $11^{\prime}$ 'i büyük ve küçük sade ve yaldızlı olmak üzere 17 tepsi, 4'ü gümüş, 25'i bakır olmak üzere 29 muhtelif maksatlı leğen, 10 porselen fincan, çoğunluğu porselen 40 kase, 72'si porselen, 10'u hatâyî, 20'si bakır, 24'ü gümüş olmak üzere 126 tabak, 12'si bakır ve 4'ü gümüş olmak üzere 16 ibrik, 3'ü gümüş 5 kahve ibriği, gümüş ve pirinçten imal edilmiş 24 şamdan ve bunlara ait gümüş süslemeli 4 şamdan sofrası mevcuttu. Ev eşyalarından minder, kilim, seccade ve yasdık da önemli yer tutmaktadır. Toplam 48 kilim olup, bunlardan 26'sı küçük, 2'si Bağdadî ve 19'u ise köhnedir. Yine toplamda 25 minder mevcut olup, 16'ü köhne kumaş, $5^{\prime}$ i işlemeli kumaş ve $3^{\prime}$ ü sade kumaştan yapılmıştır. Seccadeler kumaşları ve menşeleri bakımından çok farklıdır. Toplam 13 seccadeden Banaluka ve Uşak menşeli olanlar yanında kimi halı ve kimi işlemeli modelleri mevcut olup içlerinde bir kısmı da köhne olarak ayrılmıştır. Yasdıklar ise sade kadife, köhne, cedîd, Bursa menşeli ve süslemeli çeşitleri olup, toplam 72 adettir. Bunlardan 21'i koltukları ile birlikte olduğu belirtilmiştir. Bunlara ilave olarak yatak, yatak örtüsü, tütün tablası ve kesesi, hoşaf tepsisi, kahve askısı, makremesi, şeker kutusu, sahan, yağlık, yemeni, havlu, yemek peşkiri, tesbih gibi çok sayıda eşyalar mevcuttu.

Muhallefat arasında sayıca önemli miktarda giyim eşyası ve kumaşlar yer almaktadır. Giyim eşyaları arasında da kürk ve kürk çeşitleri öne çıkmaktadır. Bunları yapıldığı hayvan çeşitlerine göre ele alırsak; vaşak, samur, karsak, kakum, sincap, beyaz tilki başta gelmektedir. Özellikle vaşak, tilki ve karsak nâfesi kürkler tercih edilmiştir. Kürklerde kullanılan kaplama kumaşlar ise mor, limonî, fıstıkî, yeşil, sarı, mavi, turuncu, gümüş renkli ve bir kısmı da ipeklidir. Kürkler aba, kontuş, ferâce, biniş , boğaz, cübbe ve beden giysisi şeklindedir. Yine üst elbise olarak ipekli kerrake, çok çeşitleri olan kaftan, farklı kumaşlardan imal edilmiş

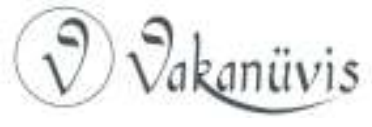


binişler önemli yer tutmaktadır. Bunlardan başka yağmurluk, entari, sarık, kuşak, hamam takımları, çizme, ayakkabı, mest vb. giyim kuşam çeşitleri vardır. Kumaşlar ise keten, pamuk ve ipek olup, bunlar genelde Orta Doğu ve Hindistan menşelidir. Çoğunluğu Şam, Halep, Acem, Hindistan'da yapılmıştır. Muhallefat arasında çok sayıda kumaş ve kumaş çeşitliliği mevcuttur. Osmanlı ülkesinde görülen ve dokunan her türlü kıymetli kumaşın defterde varlığı dikkat çekmektedir. Başta kemhâ, hatâi, atlas, şâli, hâre, kenevir, dârâyî, zerbeft olmak üzere çok miktarda kumaş çeşitleri kayıtlıdır. Listede miktarı belirtilen 1.106 zira, 33 top ve 131 taka (top) kumaş mevcuttur. Bunlara ilave olarak Ahmed Paşa'nın giyim eşyaları ve kumaşları arasında don, uçkur, sarık, gömlek, hilat abası ve ihram vardır.

Mercidabık'da mevcut olan muhallefat arasında silahın çok az olduğu dikkat çekmektedir. Silah olarak sade ve gümüş 9 adet tabanca mevcut iken bunların kılıflarının ise çoğunluğu gümüş ve sırmalıdır. Bunun dışında 4 adet tüfekçi kalkanı ve 2 adet gümüş kılıç bulunmaktadır.

Ahmed Paşa'ya ait kitaplar ise daha çok dini ve tarihi mahiyyettedir. Söz konusu kitaplar arasında Mushaf, Raşid Târihi, Divan-ı Nabî, Gayetü'l-Beyân me‘a Havassü’l-Kur'an, Ravzatü'l-Evliyâ me‘a Fıkh-ı Ekber, Divânü'l-Hâfız, Ali Kârî, Târih-i Peçevî yer almakatdır.

Muhallefat arasında yük ve binek hayvanlarının sayısının fazlalığı da dikkat çekmektedir. Bunun Ahmed Paşa'nın Erzurum'dan bölgeye yeni dönmesi ve henüz hareket halinde olmasından kaynaklandığı tahmin edilebilir. Yük ve binek hayvanları olarak deve, katır, at, beygir olmak üzere 389 baş hayvan mevcuttur. Bunlar arasında 132 baş deve, 250 baş katır dışında doru at, kır at mevcut olup, birkaç tane de beygir vardır.

Ahmed Paşa'nın biri Gürcü olmak üzeri diğerlerinin milliyeti belirtilmeyen 15 kölesi vardı. Son olarak Ahmed Paşa'nın Azez'de mevcut 452 kantar pamuk kozağı da damadı Süleyman tarafından teslim edilmiştir. Söz konusu pamuk kozağının kantarı 15 akçeden satılmış ve 6.780 akçe gelir elde edilmiştir.

Ahmed Paşa'nın Mercidabık'ta vefat ettiği sırada yanında bulunan 621 kalem muhallefatın satışından 86.543 kuruş 40 akçe gelir elde edilmiştir.

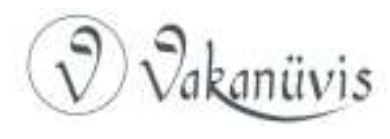


Ahmed Paşa diğer bir grup eşyasını da Kilis tarafına gelirken Antep'te Seyyid Muhammed Battal Ağa'ya emanet etmiştir. Söz konusu eşyalar da Silahşor-ı Hassa Musa Ağa tarafından zabt edilerek sayılmış ve Halep'e nakl edilerek satılmıştır. Bunlar toplamda 69 kalem eşyadır. Genel olarak porselen ve gümüşten yapılmış tepsi, tabak, ibrik, sahan, gergeden boynuzundan kase, bakırdan leğen, pirinç şamdan gibi günlük kullanılan eşyalar vardır. Bunun dışında sade, sırmalı ve gümüşten eğerler, bir miktar İngiliz ve Fransız menşeli kumaş, eski ve yeni kilimler, zırh takımları, ok ve yay takımları yanında şişhane, kaval ve balık dişi kundaklı tüfekler bulunmaktaydı. Bunların satışından da 6.459,5 kuruş gelir elde edilmiştir.

Yine Ahmed Paşa'nın damadı Süleyman'ın Ruha'da olan mütesellimi ahali tarafından tazyike maruz kalmıştır. Bunun üzerine mütesellim firar ederek Süleyman'ın dairesine gelmiştir ki burada bulunan eşya da zabt edilerek satılmıştır. Süleyman'ın yanında bulunan eşya 33 kalem olarak listelenmiştir. Söz konusu eşyalar içinde zinciri ile birlikte gümüş kemer takımı, eğer, gaddâre, topuz, üzengi, muhtelif kesme, yine muhtelif kürk çeşitleri, kaftan, donluk kumaşlar, gömlek, sarık, yasdık, kilim, seccade, şamdan, ibrik yer almaktadır. Bunların dışında 3 tabanca, gümüş kılıç, gümüş tabanca kılıfları yanında 29 deve ve 16 katır mevcuttu. Bunların da satışından 4.766 kuruş gelir elde edilmiştir.

Ahmed Paşa'nın hazinedarı Selim'in yanında olan eşyalar da müsadere edilerek satılmıştır. Hazinedar Selim'in yanında olan eşya ise 72 kalemden mürekkeptir. Bunlar içinde yük ve binek hayvanları takımları olarak zincirleriyle birlikte gümüş kemer takımı, gümüş kaplama demir üzengi, kadife eğer, gümüş gaddâre, Şam, Leh ve Bağdat menşeli kesme ve haşeler yer almaktadır. Giyim eşyaları olarak yağmurluk, şalvar, gömlek, kuşak, sarık , peştamal dışında çok sayıda muhtelif kürk bulunmaktadır. Bunlar arasında sansar biniş kürk, fıstıkî sofa kaplı sincap kürk, laciverd kumaşa kaplı boğaz kürk, kırmızı kumaşa kaplı nâfe kürk, yeşil kumaşa kaplı kontuş kürk, siyah sof kerrâke, kakum kürk yer almaktadır. Yine Hazinedar Selim'in yanında kumaşlar da vardı. Acem kutnî, geylanî kutnî, Halep menşeli keremsut ve kutnî ve keremsutu bunlardan bazıları olarak sıralanabilir. Bunların dışında biri Gürcü asıllı 5 köle olduğu satış listesinden anlaşılmaktadır. Yük ve binek hayvanı olarak iki yağız at, birer doru ve kır at dışında 21 deve ve 17 katır

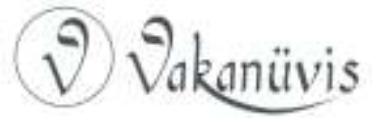


bulunmaktaydı. Hazinedar Selim'in yanında bulunan muhaleffatın satışından ise 5.929, 5 kuruş gelir elde edilmiştir.

Ahmed Paşa'nın vefatından sonra bazı mahallerde ve kişilerde bir miktar daha nakit parası ortaya çıkmıştır. Bunlar da müsadere edilerek zabt edilmiştir. Bunlardan ilki vefatı esnasında hazinesinde olup Mercidabık'ta sayıma dahil edilen ve leventlerin ulufeleri için baş ağasının aldığı 8.700 kuruştur. Diğeri ise oğulları Ömer ve Abdullah Bey'in adlarına sened olarak yazılan Halep tüccarından Emiroğlu El-Hac Abdülkadir'den tahsili gerçekleştirilen 20.000 kuruştur. Son olarak da eski Halep muhassılı Ahmed Paşa'da olan 3.000 kuruş alacağıdır ki bunların toplamı da 31.700 kuruşa tekabül etmektedir.

Bunun dışında yine Ruha'da Yağ Safa denilen mahalde sakin Saatçi Eyüp'ün hanesinde zuhur eden bir miktar daha nakit vardı. Bunlar Mustafa Paşa'nın huzurunda sayılmış ve mirî için el konularak Halep'e gönderilmiştir. Bunlar arasında zer-i mahbûb (altın para), zincirli, tuğralı, fındık ve Venedik altınlarıdır ki toplam 107.781 kuruş 1 akçedir. Hanesinde zuhur eden akçeden vakıf icaratından olmak üzere derya yıldız, zincirli ve fındık altınların miktarı ise 112.329 kuruş 80 akçedir. Yine Ahmed Paşa'nın hanesinde zuhur eden ancak Saatçi Eyüp'ün kendi malı olarak iddia ettiği zer-i mahbûb ise 2.774 kuruş 90 akçeye tekabül etmektedir. Söz konusu nakitler toplamı ise 122.886 kuruş 10 akçedir.

Ahmed Paşa'nın damadı Halep'te haps edilmiş ve muhallefat ile ilgili burada sorgulanmıştır. Bu sorgulama sonucunda Ahmed Paşa'nın Ruha'da olan hanesinde iki mahalde daha nakitlerinin gömülü olduğu ortaya çıkmıştır. Söz konusu nakitler Rakka Valisi Mustafa Paşa tarafından mirî için el konulup Halep'e gönderilmiştir. Bunlarında miktarı 187.856 kuruş 85 akçedir.

Tablo-1: Ahmed Paşa'nın Mercidabık'ta olan muhallefatının satış ve masraf icmali ${ }^{29}$

\begin{tabular}{|l|l|}
\hline $\begin{array}{l}\text { Mercidabık'taki muhallefattan elde edilen } \\
\text { gelir }\end{array}$ & Hasılat \\
\hline $\begin{array}{l}\text { Ahmed Paşa'nın ordusundaki muhallefatın } \\
\text { satışı }\end{array}$ & 93.003 kuruş \\
\hline
\end{tabular}

${ }^{29}$ D.BŞM.d. nr. 2838, s. 8-10.

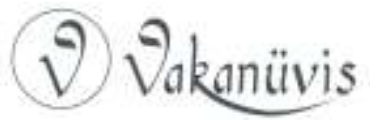




\begin{tabular}{|c|c|}
\hline Damad'ı Süleyman yanındaki eşyanın satışı & $4.766,5$ kuruş \\
\hline Hazinedarı Selim'in yanındaki eşyanın satışı & 5.929 kuruş \\
\hline Ara toplam & 103.699 kuruş \\
\hline Katip ve dellâliye masrafı & 2.592 kuruş \\
\hline Toplam hasılat & $\begin{array}{l}101.107 \text { kuruş } 1 \\
\text { rubu' }\end{array}$ \\
\hline \multicolumn{2}{|l|}{$\begin{array}{l}\text { Bazı mahallerde ortaya çıkan nakit ve } \\
\text { akçeler }\end{array}$} \\
\hline $\begin{array}{l}\text { Ahmed Paşa'nın hazinesinden baş ağasının } \\
\text { aldığı akçe }\end{array}$ & 8.700 kuruş \\
\hline $\begin{array}{l}\text { Oğullarının Emiroğlu El-Hac Abdülkadir'den } \\
\text { alacağı }\end{array}$ & 20.000 kuruş \\
\hline Halep muhassılının borcu & 3.000 kuruş \\
\hline Ara toplam & 31.700 kuruş \\
\hline \multicolumn{2}{|l|}{$\begin{array}{l}\text { Ruha'da Saatçi Eyüp'ün hanesinde ortaya } \\
\text { çıkan altınlar }\end{array}$} \\
\hline $\begin{array}{l}\text { Muhtelif zincirli, tuğralı, fındık ve Venedik } \\
\text { altını }\end{array}$ & $\begin{array}{l}107.781 \text { kuruş } 80 \\
\text { akçe }\end{array}$ \\
\hline $\begin{array}{l}\text { Hane-i mezburda vakıf gelirlerinden oluşan } \\
\text { muhtelif altın }\end{array}$ & $\begin{array}{l}112.329 \text { kuruş } 80 \\
\text { akçe }\end{array}$ \\
\hline $\begin{array}{l}\text { Hane-i mezburda Eyüp'ün kendisinin } \\
\text { olduğunu iddia ettiği altın }\end{array}$ & 2.774 kuruş 90 akçe \\
\hline Ara & $\begin{array}{l}122.886 \text { kuruş } 10 \\
\text { akçe }\end{array}$ \\
\hline Ruha'da iki mahalde gömülü bulunan altın & $\begin{array}{l}187.856 \text { kuruş } 85 \\
\text { akçe }\end{array}$ \\
\hline Genel Toplam & $\begin{array}{ll}443.550 & \text { kuruş } 5 \\
\text { akçe }\end{array}$ \\
\hline $\begin{array}{l}\text { Mercidabık'taki muhallefattan yapılan } \\
\text { masraflar }\end{array}$ & Masraf miktarı \\
\hline $\begin{array}{l}\text { Ahmed Paşa'nın kapısında olan askere verilen } \\
\text { ulûfe }\end{array}$ & 40.472 kuruş \\
\hline Asker taifesinin reislerine elden verilen akçe & 9.500 kuruş \\
\hline Techiz, tekfin, iskat-ı salat vb. masraflar & 553 kuruş \\
\hline $\begin{array}{l}\text { Deve ve katırların satışı yapılıncaya kadar olan } \\
\text { masrafları }\end{array}$ & 2.070 kuruş \\
\hline
\end{tabular}




\begin{tabular}{|l|l|}
\hline Kars ve Van askeri hazinesine gönderilen akçe & 300.000 kuruş \\
\hline Genel Toplam & $\mathbf{3 5 2 . 5 9 5}$ kuruş \\
\hline Bakiye & $\mathbf{9 0 . 9 5 5}$ kuruş $\mathbf{5}$ akçe \\
\hline
\end{tabular}

Sonuç olarak Ahmed Paşa'nın satılan eşyası, zuhur eden alacakları ve nakitleri toplamı 443.550 kuruş 5 akçe olarak gerçekleşmiştir. Ahmed Paşa'nın eşya satışı, alacak ve nakitlerinden elde edilen gelirlerin büyük kısmı bazı masraflar için sarf edilmiştir. Öncelikle Ahmed Paşa'nın kapısında olan levent, tüfekçi, baratalı, beşli piyade, kara kullukçu, enderun hizmetlilerine 40.472 kuruş verilmiştir. Yine söz konusu askerlerin reislerine 9.500 kuruş elden verilmiştir. Ahmed Paşa'nın techiz, tekfin, ıskat-ı salat, kabir ve sadaka masrafaları olarak 553 kuruş harcanmıştır. Yine deve ve katırları rayic fiyatttan satılması için 45 gün bekletilmiş ve bu süre içinde bunlar için 2.070 kuruş masrafları olmuştur. Bunlardan başka esas büyük masraf Kars ve Van'da bulunan ordu için yapılmıştır. Söz konusu bölgede bulunan ordu için 300.000 kuruş gönderilmiştir. Böylelikle Ahmed Paşa'nın muhallefat gelirlerinden 352.595 kuruş masraf edilmiş ve 90.955 kuruş 5 akçe hazineye kalmıştır. ${ }^{30}$

\subsection{Hamalızâde Ahmed Paşa'nın Ruha'da Müsadere Edilen Muhallefatı}

Hamalızâde Ahmed Paşa'nın Rakka eyaletinin paşa sancağı olan Ruha (Urfa)'da olan muhallefatı ${ }^{31} 17$ Eylül 1745 (20 Şaban 1158) tarihinde satışı yapılmıştır. Söz konusu muhallefat Rakka Valisi Mustafa Paşa tarafından mirî için zabt edilerek sayım yaptırılmış, Dergah-ı ali kapıcıbaşılarından Hasan Ağa tarafından Halep'e nakl edilmiştir. Burada ise rayiç üzere satılması için Abdullah Efendi'ye teslim edilmiştir. Hamalızâde Ahmed Paşa'nın Ruha'da tahrir olunup zabt edilen ve daha sonra Halep'e nakl olunan muhallefatı D.BŞM.MHF.d. 12567 numaralı defterde teferruatlı şekilde kaydedilmiştir. Söz konusu defterde Ahmed Paşa'ya ait toplam 499 kalem muhallefat kaydedilmiştir. Bunlardan 222'si Ahmed Paşa'nın Ruha'da zabt olunan eşyası, 17'si Damadı Süleyman'ın ve Hazinedarı Selim'in yanlarında olan eşya ve 102 'i ise

${ }^{30}$ D. BŞM.d. nr. 2838, s. 2-10 (25 Receb 1158/28 Ağustos 1745).

${ }^{31}$ Orhan Kılıç, a.g.e, s. 61.

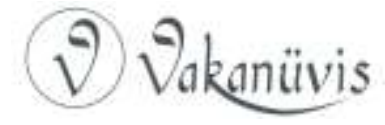


Damadı Süleyman'ın Ruha'da yanında olup Halep'e götürülüp satılan eşyalar, 158'i ise yine Ruha'da hazinedarı Selim'in yanında olup Halep'te satılan eşyalardan oluşmaktadır.

Ruha'daki muhallefatın tamamı ele alındığında ev eşyası ve günlük kullanım malzemeleri 178 kalem ile çoğunluğu oluşturmaktadır. Bunlar içinde tepsi, sini, ibrik, leğen, tas, kahve takımı, nargile takımı, maşraba, yemek sehpası, tütün tablası, tabak yanında şamdan sofrası, buhurdan ve kılapdânların önmeli kısmının gümüş, az bir kısımın da porselen olduğu görülmektedir. Muhallefat arasında muhtelif yasdık çok önemli yer tutmaktadır. Bu minvalde köhne ve müstâmel Bursa yasdık 40 çift, köhne işlemeli Bursa yasdığı 15 çift, cedîd Bursa yasdığı 12 çift, köhne döşeme kadife yasdık 32 çift, müstâmel kadife yasdık 21 çift, işlemeli kadife yasdık 7 çift, işlemeli müstâmel yasdık 4 çift ve köhne yalın yasdık ise 3 çift olmak üzere 144 çift yasdık mevcuttur. Köhne işlemeli seccade, ipek ve keçe yanında 2 halı, 5 kumaş, 4 köhne Mardin ve Kars seccadesi olmak üzere 14 muhtelif seccade vardır. Yine çok sayıda halı ve kilim vardır. Bunlar arasında yapım yerlerine göre, Uşak, Bağdat, Tükmen halı ve kilimleri mevcut olup olup bunlar arasında parlak yapısı olan barak kilimi çoğunluktadır. Toplam 117 kilimden 88'i barak kilimdir. Bir diğer ev aşyası ise minderdir. Bunların sayısı 67 olup, içlerinde Londra, Mardin yanında işlemeli, çoğunluğu kumaş kaplama olup eskidir. Ev eşyaları içinde yorgan, yorgan yüzü, perde, havlu, fener, tütün kesesi, şamdan, sofra, peşkir, berber takımı, tarak gibi bir çok malzeme mevcuttur.

Ahmed Paşa'nın Ruha'daki muhallefatı arasında kumaş önemli yer tutmaktadır. Kumaş miktarı belirtmek için adet dışında taka, zira ve top kullanılmıştır. Toplam 93 kalem kumaş olup, miktarı belirtilenler ise 59 taka, 1328 zira ve 378 toptur. Kumaş satışından 4.279 kuruş elde edilmiştir. Kumaşın hemen hemen her çişidi mevcut olup, keten, dibâ, elvan, atlas, kemhâ, dârâyî, kutnî, keremsut, hâre, şâlî, çitâre, hatâyî, zerbeft, canfes başlıcalardır. Menşelerine göre Bağdat, Halep, Mardin, Trabzon, Fransız, Londra, Hindi, Acem, Diyarbekir, Keşan ve Şam kumaşları bulunmaktadır. Pamuklu, ipekli, ketenli olmalarının yanında sade ve sırmalıdır.

Giyim eşyaları da 87 kalem olarak listelenmiş ve 4.084,5 kuruşa satılmıştır. Bunlar arasında gömlek, kuşak, sarık, kerrake, ferâce, kaftan, dülbend, şal, entari, aba, peştamal, hamam takımı, kemer takımı, çizme,

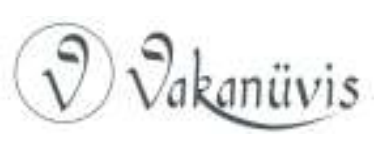


ayakkabı, mest, biniş, kürk vb. giyim kuşam eşyaları yer almaktadır. Bunlardan kürk hem çeşitlilik hem de sayı bakımından dikkat çekmektedir. Söz konusu kürkler genelde samur, tilki, karsak, vaşak, sincap, kakum gibi hayvanlardan yapılmış olup, yeşil, kırmızı, neftî, sarı, angurî, gül penbe, mavi ve gümüşî renkli kumaşlara kaplıdır.

Yük ve binek hayvanları ve bunlara ait binit takımları da mevcuttur. Yük ve binek hayvanı olarak 14 deve dışında katır, at, kısrak ve taylar 31 tane olup bunların tamamı ise yaşlılık, sakat veya küçük olmasından dolayı kullanıma uygun değildir. Binit takımları ise kemer takımı, üzengi, kesme, haşe, nal, mıh, tapkur, dizgin, eğer, topuz ve gaddâreden oluşmaktadır. Kemer takımı ve üzengilerin tamamına yakını gümüştür. Kesmeler Bağdat, Mardin menşeli olup, muhtelif kumaş ve renklerden yapılmıştır.

Bir diğer kalem ise silah ve bunlara ait mühimmattır. Bunlar arasında 118 kurada, 10 kaval, 18 sarma ve $11^{\prime}$ i normal olmak üzere 85 tüfek, 2 çift piştov, 13 kılıç olup bunlardan biri altın diğerleri gümüşten yapılmıştır. Ayrıca 32 gümüş gaddâre, 24 topuz yanında, bıçak, balta, hançer ve bunlara ait muhafaza kapları yer almaktadır.

Muhallefat arasında 24 cild kitap mevcut olup, bunların çoğunluğunu mushaf ve köhne kitaplar oluşturmaktadır. Yine 8 cariye ve 34 köle olup, bunların 15'i Gürcü kökenlidir.

Ahmed Paşa'ya ait gayr-i menkuller de bulunmaktadır. Bunlar 31 dükkan, 2 değirmen, bir arsa, bir bahçe ve bir büyük evdir. Yine mücevherat ve süs eşyası kapsamında altın bilezik, kuşak ve saatleri mevcuttur.

Ahmed Paşa'nın Ruha'da olan muhallefat satışından ise 220.132 kuruş hasılat olmuştur. Söz konusu hasılattan 199.066 kuruşu Bağdat kalesinde mevcut yeniçerilere maaş, kumaş ücreti, cebecilere ve doğancılara et ücreti olarak gönderilmiştir. Kalan 10.934 kuruş ise bazı borçları, dellaliye ücreti, bazı eşyaların İskenderun iskelesine nakliye ücreti vb. masraflar için harcanmıştır. Böylelikle Ahmed Paşa'nın Ruha'da olan muhallefatından yapılan harcamalar sonucu 10.099 kuruş kalmıştır (20 Şaban 1158/17 Eylül 1745). ${ }^{32}$

${ }^{32}$ D.BŞM.MHF.d. nr. 12567 , s. 1-7.

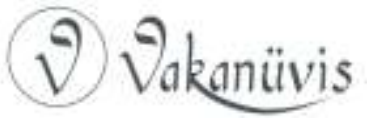


Tablo-2:Ahmed Paşa'nın Ruha'da olan muhallefatının satış ve masraf icmali ${ }^{33}$

\begin{tabular}{|c|c|}
\hline $\begin{array}{l}\text { Ahmed Paşa'nın Ruha'daki muhallefatından } \\
\text { satış }\end{array}$ & Hasılat (kur \\
\hline Ahmed Paşa'nın Ruha'daki eşya ücreti & $\begin{array}{l}20.803 \text { kuruş } 1 \\
\text { rubu' }\end{array}$ \\
\hline Ruha'dan hazinesinden gelen nakit & $11.137,5$ kuruş \\
\hline Ruha-Halep-ìstanbul'da satılan muhallefat & 90.955 kuruş \\
\hline Damadı Süleyman'ın nukûd ve eşyası & 65.509 kuruş \\
\hline Hazinedarı Selim'in nukûd ve eşyası & $\begin{array}{l}31.726,5 \text { kuruş } 1 \\
\text { rubu' }\end{array}$ \\
\hline Toplam & 220.132 kuruş \\
\hline $\begin{array}{l}\text { Ahmed Paşa'nın Ruha'daki muhallefatından } \\
\text { yapılan masraflar }\end{array}$ & Meblağ \\
\hline Bağdat kalesinde bulunan yeniçerileri mevacibi & uş \\
\hline $\begin{array}{l}\text { Bağdad kalesinde bulunan yeniçerilerin çuha } \\
\text { ücreti }\end{array}$ & $9.232,5$ kuruş \\
\hline $\begin{array}{l}\text { Bağdat kalesinde bulunan cebecilerin lahm } \\
\text { ücreti }\end{array}$ & 1.457 kuruş \\
\hline $\begin{array}{l}\text { Bağdat kalesinde bulunan doğancıların lahm } \\
\text { ücreti }\end{array}$ & $1.797,5$ kuruş \\
\hline $\begin{array}{l}\text { Bağdat kalesinde bulunan top arabacılarının } \\
\text { lahm ücreti }\end{array}$ & $\begin{array}{l}\text { 1.363,5 kuruş } 15 \\
\text { para }\end{array}$ \\
\hline Antep'te El-Hac Ahmed Ağa'ya olan borcu & 4.000 kuruş \\
\hline $\begin{array}{l}\text { Davudzâde Mustafa Efendi'nin vasisi Mustafa } \\
\text { Efendi'ye olan borcu }\end{array}$ & 432,5 kuruş \\
\hline Es-Seyyid Mustafa Efendi'ye olan borcu & 5.000 kuruş \\
\hline $\begin{array}{l}\text { Damadı ve hazinedarının eşyasının Ruha'dan } \\
\text { Halep'e nakliye ücreti }\end{array}$ & $\begin{array}{l}366,5 \text { kuruş } 1 \\
\text { rubu' }\end{array}$ \\
\hline İskenderun iskelesine eşya nakliye ücreti & 325,5 kuruş \\
\hline Dellâliye ücreti & 861 kuruş 1 rubu' \\
\hline Toplam & 210.033 kuruş \\
\hline Kalan & 10.099 kuruş \\
\hline
\end{tabular}

${ }^{33}$ D.BŞM.MHF.d. nr. 12567, s. 4-7.

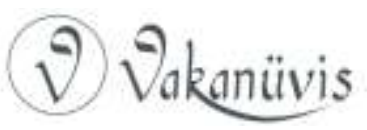


Ahmed Paşa'nın Ruha'da olan muhallefatını ihtiva eden 12567 numaralı defter ekte verilmiştir. Söz konusu defterde paşanın eşya, hayvan, silah, kumaş, köle vs. listeleri ve bunların satışından elde edilen hasılat mufassal ve icmal olarak yer almaktadır. Diğer taraftan söz konusu muhallefat satışından elde edilen gelirlerin harcama kalemleri de mevcuttur (EK-1).

\section{Sonuç}

Hamalızâde Ahmed Paşa, XVIII. yüzyılın ilk yarısında uzun süren Osmanlı-Iran savaşları döneminde muhtelif aralıklarla Rakka valiliği yapmıştır. 1731-1745 yılları arasındaki Rakka valiliği esnasında bazen İran'a karşı sınır bölgelerinde ve bazen bazı eşkıya gruplarının tenkili için Anadolu'da görevlendirilmiştir. Bağdat Seraskeri Ahmed Paşa'nın Kirmanşah ve Hemedan taraflarına düzenlediği seferlerde paşanın kethüdası olarak görev almıs, bundan sonra Hemedan, Musul, Kerkük, Bağdat ve Erzurum'da muhafızlıklarda bulunmuştur. İran Seraskeri Abdullah Paşa'nın Kars yakınlarında şehit düşmesi ile kısa süre bu görevi vekaleten yürütmüştür. 1738 yılında Aydın taraflarında ortaya çıkıp Denizli-Manisa taraflarında geniş bir alanda eşkiyalık yapan Sarıbeyoğlu Mustafa'nın ortadan kaldırılmasında aktif rol almışır. Valilik yıllarının son dönemlerinde İran savaşları için yine Erzurum ve Kars taraflarında görev almıştır.

1744 yııında Kars seraskeri iken hem yaşının ilerlemiş olması hem de ortaya çıkan hastalıklarının ilerlemesi üzerine bu görevinden ayrılıp Erzurum'a geçmiştir. Daha sonra Rakka'ya dönme talebinde bulunmuştur. Bu talebi kabul görmüş ancak valilik yıllarında ahaliye karşı son derece gaddar davranması, vergi tahsilinde zulme varan uygulamaları sebebiyle Rakka halkı onun buraya dönmesine mani olmuştur. Hatta ahaliden seçilen birkaç kişi i̇stanbul'a giderek Ahmed Paşa'nın halka yaptığı haksız uygulamaları delilleriyle birlikte izah etmişler ve onun Rakka'ya vali olarak dönmesini istemediklerini beyan etmişlerdir. Osmanlı yönetimi bu şikayeti yerinde bulmuş olmalı ki Ahmed Paşa'nın valilik görevinden azl edilerek Rodos'a sürülmesi konusunda ferman göndermiştir. Ancak Ahmed Paşa etrafında topladığı 10 binden fazla adamı ile Kilis ve Antep taraflarına geçmiş, tebliğ edilen görevi kabul konusunda merkezi hükümeti oyalama yolunu seçmiştir.

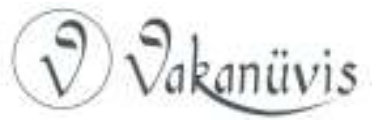


Etrafındaki kalabalık gruplarla birlikte her an için bir isyan çıkma ihtimali de mevcuttu. Osmanlı yönetimi yeni bir ferman çıkarmış ancak bu ferman daha tebliği edilemeden Mercidabık'da eceli ile vefat etmiştir.

Ahmed Paşa'nın muhallefatı incelendiğinde çok fazla servet biriktirdiği görülmektedir. Bir vali olarak menkul ve gayr-i menkullerinin dikkat çekecek kadar fazla olmasının iki sebebi olmaladır. Bunlardan biri her ne kadar bazı fasılalar da olsa uzun süre aynı yerde valilik yapması temel etken olmalıdır. Osmanlı eyalet yöneticilerinin sık sık görev yerlerinin değiştiği bilinen bir durumdur. Diğer bir sebep ise Rakka valiliğini "ber-vech-i mâlikâne" suretiyle tasarruf etmesidir. XVIII. yüzyılda malikane usulünde müzayede sistemi olduğu için devlete taahhüt edilen meblağın çok daha fazlası ahaliden toplanmaktaydı. Zaten belgelerde gördügümüz kadarıyla kendisi de vergi konusunda gaddar, ceberrut ve zulme varan acımasız uygulamaları sebebiyle azl edilmiştir.

Ahmed Paşa, edindiği servetle rahat ve zengin bir hayat sürmesi muhtemeldir. Muhallefatı arasında yer alan kıymetli ipekli yerli ve yabancı kumaşlar Osmanlı' da en önemli zenginlik kaynaklarından biridir. Ev eşyaları, mutfak malzemeleri ve silahlarında porselen, bakır, gümüş ve hatta altının varlığı ihtişamlı bir hayatın göstergesidir. Yine giyim kuşam eşyalarında özellikle ipekli, kürklü giyisiler de çok önemlidir. Damadı ve hazinedarı tarafından farklı yerlerde saklanan ve ortaya çıkarılan gerek eşya ve gerek altınların varlığı ayrı bir konudur. Yine kapı halkının fazlalığından olmalıdır ki yük ve binek hayvanları da oldukça çoktur. Gayr-i menkulleri içinde yer alan dükkan, ev, arsa, değirmen ve bahçe bulunmaktadır. Bunlar arasında dükkan sayısı da valinin edindiği servetin boyutlarını anlamak için yeterli fikir vermektedir.

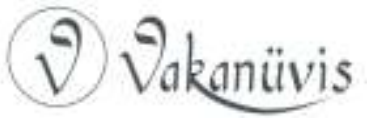




\section{Kaynakça}

\section{Osmanlı Arşivi}

Bab-ı Defteri Başmuhasebe Kalemi Defterleri (D.BŞM.d.), nr. 2838.

Bab-ı Defteri Başmuhasebe Kalemi Muhallefat Defterleri (DBŞM.MHF.d.), nr. 12567.

Ali Emiri, Sultan Mahmud I (AE. SMHD.), nr. 926, 10683, 14288, 21171.

Cevdet, Dahiliye (C.DH.), nr. 7698.

\section{Kitap, Araştırma, inceleme}

Ayverdi, Illhan, Misalli Büyük Türkçe Sözlük, C. 3, Kubbealtı Neşriyat, İstanbul 2006.

Canatar, Mehmet, "Kethüdâ", DiA, C. 25, Ankara 2002, s. 332-333.

Baki Çakır, Osmanlı Mukataa Sistemi (XVI-XVIII. Yüzyıl), Kitabevi, İstanbul 2003

Dingeç, Emine, "18. Yüzyılın İkinci Yarısında Saray Atlarının Binit Takımları", Uludağ Üniversitesi Sosyal Bilimler Dergisi, Yıl: 12, Sayı: 20 (2011/1), s. 1-20.

Günay, Mehmet, Ruha Valisi Hamalızâde Ahmed Paşa'nın Vekâyi'i (11561158), Basılmamış Yüksek Lisans Tezi, İstanbul 1994.

Ertaş, Mehmet Yaşar, "XVIII. Yüzyılda Bir Osmanlı Eşkıyası: Sarıbeyoğlu Mustafa", Uluslararası Denizli ve Çevresi Tarih ve Kültür Sempozyumu, Bildiriler, (6-8 Eylül 2006), C. I, Denizli 2007.

İzî Süleyman Efeni, izzî Tarihi (Osmanlı Tarihi, 1157-1165/1744-1752), Haz. Ziya Yılmazer, Türkiye Yazma Eserler Kurumu Başkanlığı Yayınları, İstanbul 2019.

Karagöz, Hakan, "Bir Alman Kaynağının İzlenimlerine Göre Sarıbeyoğlu İsyanının Batı Anadolu'daki Etkileri", Süleyman Demirel Üniversitesi FenEdebiyat Fakültesi Sosyal Bilimler Dergisi, Kemal Göde Armağan Sayısı, Isparta 2013, s. 197-198.

Kılıç, Orhan, 18. Yüzyılın Ilk Yarısında Osmanlı Devleti'nin Idari Taksimatı, Eyalet ve Sancak Tevcihatı, Ceren Matbaacılık, Elazığ 1997.

Koçu, Reşat Ekrem, Türk Giyim, Kuşam ve Süslenme Sözlüğü, Sümerbank Kültür Yayınları, Ankara 1969.

Külbilge, Illker, 141 Numaralı Mühimme Defteri (H. 1148), Basılmamış Yüksek Lisans Tezi, İzmir 2002.

Mehmed Süreyya, Sicilli Osmanî, Yay. Haz. Nuri Akbayar, C.I, Tarih Vakfı Yurt Yayınları, İstanbul 1996.

Özcan, Tahsin, "Muhallefat", DiA, C. 35, Türkiye Diyanet Vakfı, İstanbul 2005, s. 406-407.

Özvar, Erol, Osmanlı Maliyesinde Malikâne Uygulaması, Kitabevi, İstanbul 2003.

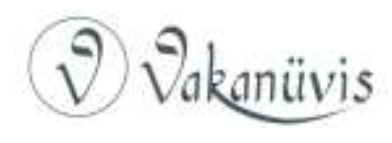


Pakalın, Mehmet Zeki, Osmanlı Tarih Deyimleri ve Terimleri Sözlüğ̈̈, C.II, Milli Eğitim Basımevi, İstanbul 1983.

Şemdâni-zâde Fındıklılı Süleyman Efendi Târihi Mür'it-Tevârih, I, Haz. Münir Aktepe, iü Edebiyat Fakültesi Yayınları, İstanbul 1976.

Tabakoğlu, Ahmet, Gerileme Dönemine Girerken Osmanlı Maliyesi, Dergah Yayınları, İstanbul 1985.

Telci, Cahit, "Osmanlı Devletinde 18. Yüzyılda Muhallefat ve Müsâdere Süreci", Tarih incelemeleri Dergisi, C. XXII, S. 2 (Aralık 2007), s. 145-166.

Uzunçarşılı, İsmail Hakkı, Osmanlı Tarihi, IV/I, Ankara 1978.

Ünal, Mehmet Ali, Osmanlı Tarih Sözlüğü, Paradigma Yayınları, İstanbul 2011.

Ünal, Mehmet Ali, “Osmanlı İmparatorluğunda Müsadere”, Türk Dünyası Araştırmaları Dergisi, S.49 (Ağustos 1987), s. 95-110.

Vak'anüvis Subhî Mehmed Efendi, Subhî Tarihi, Sâmi ve Şâkir Tarihleriyle Birlikte 1730-1744, (Inceleme ve Karşılaştırmalı Metin), Haz. Mesut Aydıner, Kitabevi, İstanbul 2007. 


\section{EKLER:}

\section{Hamalızâde Ahmed Paşa'nın Muhallefatı (D.BŞM.MHF.d. 12567)}

Sâbıkâ Rakka Vâlisi müteveffâ Ahmed Paşa'nın Ruha'da olup hala Rakka vâlisi vezîr-i mükerrem devletlü Mustafa Paşa hazretlerinin ma'rifetleri ve ma'rifet-i şer'le yine Ruha'da tahrîr ve defter ve mahûmen hıfz olunan emvâl ve eşyâ ve nukûd ve emlâki müceddeden yine vezîr-i müşârun ileyh hazretlerinin ma'rifetleri ve ma'rifet-i şer'le mahallinde tahrîr ve defter ve mahtûm defteri ile emvâl ve eşyâ-i merkûme dergâh-ı alî kapucubaşılarından izzetlü Hasan Ağa mübâşeretiyle Haleb'e nakl ve müteveffâ-yı müşârun ileyhin bâ-hıfz-ı hümâyûn şevket-makrûn emvâl ve eşyâ ve devâbb ve mevâşisi ve nükûd ve akarının cânib-i mîrî için zabt ve fürûhtuna me'mûr mîrahûr-ı evvel Hazret-i cihândâri sa'adetlü Abdullah Efendi hazretlerine teslîm olunması için emr-i âlî-şân şerefbahş sudûr eylediğinden emr ü fermân buyrulduğu üzere kapucubaşı mûmâ-ileyh Hasan Ağa vezîr-i müşârunileyh hazretlerinin ma'rifetleri ve ma'rifet-i şer'le Ruha'da tahrîr ve defter edüp mümzî ve mahtûm defteriyle Haleb'e getürüp müşârunileyh hazretlerine teslîm ve mîr-i müşârun-ileyh hazretleri Haleb'de ma'rifet-i şer' ve cümle ma'rifetiyle fürûht eyledikleri emvâl ve eşyânın defteridir ki ber-vech-i âtî zikr olunur. Tahrîren fi'l-yevmi'l-ışrîn fî şehr-i Şa'bân es-senetü semânin ve hamsîn ve mi'ete ve elf (20 Ş. 1158/17 Eylül 1745).

\begin{tabular}{|c|l|c|c|}
\hline S.No & Muhallefât & $\begin{array}{c}\text { Adet/ } \\
\text { Miktar }\end{array}$ & $\begin{array}{c}\text { Kıymet } \\
\text { (akçe) }\end{array}$ \\
\hline 1 & Mushaf-ı Şerîf Cild & 1 cild & 41 \\
\hline 2 & Def'a Mushaf-ı Şerîf & 1 cild & 28 \\
\hline 3 & Sîm kemer raht me‘a reşme & 1 & 290 \\
\hline 4 & $\begin{array}{l}\text { Def'a sîm kemer raht me‘a } \\
\text { reşme }\end{array}$ & 1 & 283 \\
\hline 5 & $\begin{array}{l}\text { Def'a sîm kemer raht me‘a } \\
\text { reşme }\end{array}$ & 1 & 255 \\
\hline 6 & Def'a sîm kemer raht & 1 & 245 \\
\hline 7 & $\begin{array}{l}\text { Def'a sîm kemer raht me'a } \\
\text { reşme }\end{array}$ & 1 & 195 \\
\hline
\end{tabular}

\section{(จ) Vakaniuivis}




\begin{tabular}{|c|c|c|c|}
\hline 8 & Sîm vasat kemer raht & 3 & 366,5 \\
\hline 9 & Sîm ince haydarî raht & 2 & 175 \\
\hline 10 & Sîm sağîr çapkun haydarî raht & 1 & 55 \\
\hline 11 & Yaldızlı ince çapkun rahtı & 2 & 124 \\
\hline 12 & Beyaz çapkun rahtı & 3 & 213 \\
\hline 13 & İnce kemer raht & 1 & 65 \\
\hline 14 & Göbeği sîm Haleb şeriti raht & 3 & 75 \\
\hline 15 & Haydarî sağîr kısrak raht & 3 & 167 \\
\hline 16 & Sîm çapkun rikâbî & 1 & 136,5 \\
\hline 17 & Sîm rikâb & 1 çift & 150 \\
\hline 18 & Sîm sağîr matara & 1 & 65 \\
\hline 19 & Def'a sîm rikâb & 1 & 159 \\
\hline 20 & Def'a sîm rikâb & 1 & 185 \\
\hline 21 & Def'a sîm rikâb & 1 & 175 \\
\hline 22 & Def'a sîm rikâb & 1 & 161 \\
\hline 23 & Haydarî sağîr kısrak rahtı & 3 & 174 \\
\hline 24 & Sîm kebîr iskemle & 1 & 440 \\
\hline 25 & Sîm sağîr iskemle & 1 & 93 \\
\hline 26 & Sîm kebîr ta'am iskemlesi & 1 & 1024 \\
\hline 27 & Sîm askı & 1 & 95 \\
\hline 28 & Sîm leğen me‘a ibrik & 1 & 138 \\
\hline 29 & Def'a sîm leğen me‘a ibrik & 1 & 193 \\
\hline 30 & Def'a sîm leğen me‘a ibrik & 1 & 152 \\
\hline 31 & Sîm sağîr leğen me‘a ibrik & 1 & 118 \\
\hline 32 & Def'a sîm rikâb & 1 & 171 \\
\hline 33 & Sîm kebîr şamdan & 1 & 136 \\
\hline 34 & $\begin{array}{l}\text { Sîm sağîr buhurdân } 2 \text { adet, } \\
\text { kılabdân } 2 \text { adet }\end{array}$ & & 117 \\
\hline 35 & Sîm sağîr kahve ibriği & 2 & 31 \\
\hline 36 & $\begin{array}{l}\text { Sîm nargile siperi 6, sîm tas } \\
\text { kapağı } 3\end{array}$ & & 122 \\
\hline 37 & Fağfûrî kılabdân & 2 & 2,5 \\
\hline 38 & Sîm sağîr buhurdân & 1 & 32 \\
\hline 39 & Sîm sağîr çıfıt işi kalemdân devât & 1 & 52 \\
\hline 40 & Sîm kılıç bağı 2, yakı bağı 1 , & & 29 \\
\hline 41 & Sîmlüce duhân tablası & 3 & 15 \\
\hline
\end{tabular}




\begin{tabular}{|c|c|c|c|}
\hline 42 & Sîm sağîr devât & 1 & 52,5 \\
\hline 43 & Sîm hançer me‘a bıçak & 1 & 26,4 \\
\hline 44 & Sîm sağîr tas kapağı & 1 & 9,5 \\
\hline 45 & Sîmlü debbûs & 1 & 54 \\
\hline 46 & Def'a sîmlü debbûs & 5 & 91 \\
\hline 47 & Def'a sîmlü debbûs & 6 & 111 \\
\hline 48 & Bulâd debbûs & 3 & 11 \\
\hline 49 & Sîmlüce gaddâre & 11 & 155 \\
\hline 50 & Demir külünk & 3 & 15,5 \\
\hline 51 & Sîmlüce kurâda kılıç & 9 & 68 \\
\hline 52 & Sîmlüce balta & 1 & 16 \\
\hline 53 & Sîmlü satır hançeri & 4 & 60 \\
\hline 54 & (yırtık) & & 90 \\
\hline 55 & Altunluca kılıç & 1 & 190 \\
\hline 56 & Karabina & 1 & 5 \\
\hline 57 & Sîmlüce vezne & 2 & 25,5 \\
\hline 58 & Sîm sağîr kahve ibriği & 1 & 14 \\
\hline 59 & Sîm sağîr maşraba & 1 & 66 \\
\hline 60 & Kurâda sîm saat & 2 & 32 \\
\hline 61 & Def'a sîm devât & 1 & 55,5 \\
\hline 62 & Sîmlüce debbûs & 3 & 41 \\
\hline 63 & Sîmlüce gaddâre & 11 & 12,5 \\
\hline 64 & Kemayâr sîm tabl-baz & 1 & 15 \\
\hline 65 & Sîm sağîr mum sofrası & 1 & 36 \\
\hline 66 & Köhne haşe & 2 & 8 \\
\hline 67 & Köhne Şam gömleği & 1 & 5 \\
\hline 68 & Köhne bayrak & 1 & 2 \\
\hline 69 & Meles ton & 12 & 15,5 \\
\hline 70 & Köhne Mardin seccâdesi & 1 & 3 \\
\hline 71 & Keten top & 1 & 7 \\
\hline 72 & Sîm zerbeft & 23 parça & 275 \\
\hline 73 & Beyaz kemhâ parça & 1 & 10,5 \\
\hline 74 & $\begin{array}{l}\text { Müsta'mel Mardin abdest } \\
\text { peşkiri }\end{array}$ & 2 & 12 \\
\hline 75 & Köhne yalın yasdık & 3 & 6 \\
\hline 76 & Elvân kadife fî 3 akçe & 15 & 45 \\
\hline
\end{tabular}




\begin{tabular}{|c|c|c|c|}
\hline 77 & Müsta'mel su dibâsı & 1 parça & 16 \\
\hline 78 & Mısır mahremesi & 4 & $\begin{array}{l}4 \text { akçe } 1 \\
\text { rubu' }\end{array}$ \\
\hline 79 & Meles gömlek & 28 & 75 \\
\hline 80 & Şam keremsûtu taka & 5 & 25 \\
\hline 81 & Halebî kutnî parça & 1 & 3 \\
\hline 82 & Keten parça & 3 & 11 \\
\hline 83 & Köhne kuşak & 1 & 8 \\
\hline 84 & Hama kuşağı & 4 & 31 \\
\hline 85 & Evrengşahî & 1 top & 11 \\
\hline 86 & Sancak bayrağı & 4 & 25 \\
\hline 87 & $\begin{array}{l}\text { Halep sandalı parça 9, bürüncük } \\
\text { kadife parça } 2\end{array}$ & & 45 \\
\hline 88 & $\begin{array}{l}\text { Fitilli bez } 2,(. . . . . .) \text { halı 1, } \\
\text { evrengşâhî parça } 3,\end{array}$ & & 33 \\
\hline 89 & Kaba çuka donluk & 2 & $\begin{array}{c}15 \text { akçe } 1 \\
\text { rubu' }\end{array}$ \\
\hline 90 & Elvân Fransız çukası donluk & 18 & 181 \\
\hline 91 & Köhne piştov & 2 çift & 13 \\
\hline 92 & Oyma ağaç devât & 1 & 12 \\
\hline 93 & $\begin{array}{l}\text { Fitilli parça 2, evrengşâhî parça } \\
\text { 1, sâde çiçekli parça } 1\end{array}$ & & 35 \\
\hline 94 & $\begin{array}{l}\text { Peştamal } 1 \text { adet, sarık örtüsü 1, } \\
\text { köhne Mardin peşkiri } 1 \text { adet }\end{array}$ & & 15 \\
\hline 95 & $\begin{array}{l}\text { Çiçekli dülbend } 1 \text { adet, akçe } \\
\text { kesesi } 1 \text { adet }\end{array}$ & & 15 \\
\hline 96 & Bir miktar mercan & & 3 \\
\hline 97 & $\begin{array}{l}\text { Sîm çelenk } 1 \text {, ağaç tesbîh } 1 \text { adet, } \\
\text { Bir miktar sırma düğme }\end{array}$ & & $\begin{array}{c}15 \text { akçe } 1 \\
\text { rubu' }\end{array}$ \\
\hline 98 & Köhne beştahta saat & 1 & 10 \\
\hline 99 & $\begin{array}{l}\text { Sîm sagîr kuşak 1, nühâs mikras } \\
2\end{array}$ & & 6,5 \\
\hline 100 & $\begin{array}{l}\text { Elvân harîr } 9 \text { deste, dülbent } 1 \\
\text { parça, dizgin } 1 \text { adet }\end{array}$ & & 10 \\
\hline 101 & $\begin{array}{l}\text { Şerbetî } 1 \text { parça, kuşak kolanı 1, } \\
\text { bir miktar harcî }\end{array}$ & & 12 \\
\hline
\end{tabular}




\begin{tabular}{|c|c|c|c|}
\hline 102 & Müsta'mel sakal tarağı & 11 & 27 \\
\hline 103 & Müsta’mel kadife yasdık & 21 çift & \\
\hline 104 & Mutallâ kadife yasdık & 7 çift & 175,5 \\
\hline 105 & Mutallâ müsta'mel yasdık & 4 çift & 45 \\
\hline 106 & Sahîr köhne ipek halı & 1 & 13,5 \\
\hline 107 & $\begin{array}{l}\text { Mutallâ Haleb hatâyisi donluk, } \\
13 \text { zira, fî } 50 \text { para }\end{array}$ & 91 & $\begin{array}{c}\text { 113,5 akçe } 1 \\
\text { rubu' }\end{array}$ \\
\hline 108 & $\begin{array}{l}\text { Haleb hâresi donluk 2, Lahorî şâl } \\
1 \text { adet }\end{array}$ & & 18,5 \\
\hline 109 & Elvân şâlî sof donluk & 9 & 133 \\
\hline 110 & Gezi keremsût & 2 taka & 14 \\
\hline 111 & Ruka' -ı muhtelife & 1 cild & 1,5 \\
\hline 112 & $\begin{array}{l}\text { Alaca sandal } 2 \text { parça, Hatâyi } 3 \\
\text { parça, Halebî bildâr } 1 \text { taka }\end{array}$ & & 23,5 \\
\hline 113 & Çitâre & 1 taka & 9 \\
\hline 114 & Çıt yorgan yüzü & 1 & 3 \\
\hline 115 & Halebî yeşimi & 1 taka & 2 \\
\hline 116 & Müteârif destâr & 5 taka & 22 \\
\hline 117 & $\begin{array}{l}\text { Yeşil kenevir donluk 1, çenber } 1 \\
\text { parça }\end{array}$ & & 16 \\
\hline 118 & $\begin{array}{l}\text { Telli hatâyî parça, } 18 \text { zira fî } 110 \\
\text { para }\end{array}$ & 112 & 308 \\
\hline 119 & $\begin{array}{l}\text { Kerrâke harcî 2, sîm künde 1, sîm } \\
\text { çalma } 1\end{array}$ & & 19 \\
\hline 120 & Sîmlüce billur kılabdân & 1 & 5 \\
\hline 121 & Kaneviz & 1 parça & 6,5 \\
\hline 122 & Def'a Halebî hatâyisi donluk & 7 & 57,5 \\
\hline 123 & Def'a kanaviz & 1 parça & 4 \\
\hline 124 & İğneli kalemdân & 1 & 9 \\
\hline 125 & Pirinç şamdân & 1 & 2,5 \\
\hline 126 & $\begin{array}{l}\text { Mutallâ müsta'mel Bursa yasdık } \\
7 \text { adet, Bâlin } 2 \text { çift }\end{array}$ & & 135 \\
\hline 127 & Sâde kadife 1 top, keten 2 top & & 35 \\
\hline 128 & Elvân Halebî hâre & 1 parça & 73 \\
\hline 129 & $\begin{array}{l}\text { Alaca kutnî } 4 \text { parça, müsta'mel } \\
\text { Acem futası } 2 \text { adet }\end{array}$ & & 18 \\
\hline
\end{tabular}




\begin{tabular}{|c|c|c|c|}
\hline 130 & Meles gömlek 21, don 48 & & 91 \\
\hline 131 & Müteârif destar & 44 taka & 172 \\
\hline 132 & Vasat çakmaklı destar & 52 taka & 415,5 \\
\hline 133 & Sâde havlu & 19 & 15,5 \\
\hline 134 & Peştamal & 3 & 8,5 \\
\hline 135 & $\begin{array}{l}\text { Beyaz evrengşahî } 1 \text { top ve } 1 \\
\text { parça }\end{array}$ & & 10 \\
\hline 136 & Yeşil hâre parça & 1 & 3 \\
\hline 137 & Yağlık 11 adet, tütün kesesi 9 & & 56,5 \\
\hline 138 & $\begin{array}{l}\text { Müsta'mel şerbet mahramesi } 2 \\
\text { adet ve sandal parçası } 1\end{array}$ & & 4 \\
\hline 139 & Kemhâ 1 parça, sandal 5 parça & & 22 \\
\hline 140 & $\begin{array}{l}\text { Acem zerbefti } 1 \text { parça, Şalî } \\
\text { donluk } 1\end{array}$ & & 23 \\
\hline 141 & $\begin{array}{l}\text { İşleme ve sâde yağlık 74, üstlük } 2 \\
\text { adet }\end{array}$ & 1 & 95 \\
\hline 142 & İşleme ve sâde uçkur & 13 & 87 \\
\hline 143 & Köhne sarık örtüsü & 2 & 10 \\
\hline 144 & Halebî camfes & 1 top & 12 \\
\hline 145 & Telli kamçı 2 adet, dürbün 1 adet & & 5,5 \\
\hline 146 & $\begin{array}{l}\text { Kahverengi kadife } 1 \text { parça, } \\
\text { Haşelik keten } 2 \text { parça }\end{array}$ & & 33 \\
\hline 147 & Halebî keremsût & 2 taka & 9,5 \\
\hline 148 & $\begin{array}{l}\text { Köhne mutallâ Bursa yasdık } 8 \\
\text { çift, bâlin } 5 \text { çift }\end{array}$ & & 98 \\
\hline 149 & Müsta'mel sâde kadife yasdık & 2 çift & 105 \\
\hline 150 & $\begin{array}{l}\text { Bağdâdî darâyî donluk 7, Haleb } \\
\text { merresi donluk } 9\end{array}$ & & 60 \\
\hline 151 & Köhne Mardin mak‘adı & 2 & 33 \\
\hline 152 & Köhne çit mak'ad & 11 & 10,5 \\
\hline 153 & Köhne basma mak'ad & 3 & 18 \\
\hline 154 & Köhne Mardin ve Kars seccâdesi & 3 & 14,5 \\
\hline 155 & $\begin{array}{l}\text { Köhne bâlin } 2 \text { çift, köhne yasdık } \\
2 \text { çift }\end{array}$ & & 9 \\
\hline 156 & Kırmızı çuka donluk & 1 & 11 \\
\hline 157 & Köhne basma çuka mak'ad & 2 & 8 \\
\hline
\end{tabular}




\begin{tabular}{|c|c|c|c|}
\hline 158 & Licam & 2 & 1 \\
\hline 159 & Yeşil Lahorî şâl & 1 & 7 \\
\hline 160 & Köhne işleme şâl kuşak & 1 & 29 \\
\hline 161 & İşleme berber takımı & 1 & 25 \\
\hline 162 & Kemerbend kuşak & 5 & 101,5 \\
\hline 163 & $\begin{array}{l}\text { Beyaz kerrâkelik sof donluk 1, } \\
\text { sandal parçaları } 3 \text { adet }\end{array}$ & & 26,5 \\
\hline 164 & Fağfûrî kılabdân & 1 & $\begin{array}{c}1 \text { akçe } 1 \\
\text { rubu }\end{array}$ \\
\hline 165 & $\begin{array}{l}\text { Müsta'mel Mardin peşkiri } 1 \\
\text { adet ve bir miktar kürk hurdesi }\end{array}$ & & 15 \\
\hline 166 & $\begin{array}{l}\text { Müsta'mel kuşak hoşab } 2 \text { deste, } \\
\text { ta'am } 2 \text { deste }\end{array}$ & & 11 \\
\hline 167 & Kaba Trabzon bezi & 1 top & 41 \\
\hline 168 & Müsta’mel yaldızlı leğen ve ibrik & 1 & 5,5 \\
\hline 169 & Dizgin 4 adet, tabkur 4 adet & & 11 \\
\hline 170 & Kırmızı çuka & 2 zira & 5 \\
\hline 171 & Köhne kütüp ve re'sâil ve inşâ & 16 & 8 \\
\hline 172 & Simlüce köhne vezne & 1 & 6 \\
\hline 173 & Müsta'mel işleme (yırtık) & & 63 \\
\hline 174 & $\begin{array}{l}\text { Çuka at gömleği } 1 \text { adet, Kırmızı } \\
\text { Bursa kesme } 1 \text { adet }\end{array}$ & & 46 \\
\hline 175 & Köhne astarsız çuka kesme & 1 & 55 \\
\hline 176 & Köhne kırmızı kesme & 1 & 70 \\
\hline 177 & Köhne çuka bârgîr kesmesi & 1 & 42 \\
\hline 178 & $\begin{array}{l}\text { Köhne çukaya kaplu beyaz tilki } \\
\text { boğazı köhne kürk }\end{array}$ & 1 & 63 \\
\hline 179 & Fransız dâne & 8 & 11 \\
\hline 180 & Cedîd tilki nâfesi kürk & 2 tahta & 42 \\
\hline 181 & Müsta‘mel Bursa yasdık & 15 çift & 85 \\
\hline 182 & Köhne barak kilimi & 28 & 44 \\
\hline 183 & Müsta'mel orta halı & 2 & 82 \\
\hline 184 & Def'a müsta'mel halı & 3 & 42 \\
\hline 185 & Def'a köhne barak kilim vezne & 14 & $\begin{array}{l}21 \text { akçe } 1 \\
\text { rubu' }\end{array}$ \\
\hline
\end{tabular}




\begin{tabular}{|c|c|c|c|}
\hline 186 & $\begin{array}{l}\text { Köhne câcim } 1 \text { adet, pencere ve } \\
\text { kapu perdesi } 2\end{array}$ & & 7,5 \\
\hline 187 & $\begin{array}{l}\text { Müsta'mel köhne çuka mak'ad } 1 \\
\text { ve basma orta } 1\end{array}$ & & 41 \\
\hline 188 & $\begin{array}{l}\text { Köhne kebîr ve sağîr çuka } \\
\text { mak'ad }\end{array}$ & 18 & 112 \\
\hline 189 & Mak'adlık şayak parça & 4 & 32 \\
\hline 190 & Yeşil çuka köhne mak'ad & 4 & 15 \\
\hline 191 & Köhne sûzenî mak'ad sadr & 4 & 23 \\
\hline 192 & Köhne basma çuka orta & 1 & 18 \\
\hline 193 & Köhne tahtrevân ortası & 1 & 15 \\
\hline 194 & $\begin{array}{l}\text { Halı seccâde 2, köhne seccâde } 2 \\
\text { adet }\end{array}$ & & 38 \\
\hline 195 & $\begin{array}{l}\text { Köhne çuka seccâde } 2 \text { adet ve } \\
\text { Acem nemdî seccâde } 1 \text { adet }\end{array}$ & & 18 \\
\hline 196 & Köhne ihrâm & 1 & 12 \\
\hline 197 & $\begin{array}{l}\text { Köhne basma çuka barata } 1 \\
\text { adet, köhne basma çuka yasdık } 1 \\
\text { adet }\end{array}$ & & 5,5 \\
\hline 198 & $\begin{array}{l}\text { Köhne çuka kapu perdesi } 3 \text { adet, } \\
\text { köhne çuka mak'ad } 3 \text { adet ve } \\
\text { nemedî seccâde } 1 \text { adet }\end{array}$ & & 25 \\
\hline 199 & $\begin{array}{l}\text { Barak kilimi } 22 \text { adet, seyishâne } \\
\text { kilimi } 4 \text { adet }\end{array}$ & & 61 \\
\hline 200 & Köhne câcim 1 adet, kilim 5 adet & & 17,5 \\
\hline 201 & Kırmızı Diyarbekir bezi & 150 top & 160 \\
\hline 202 & Ayntâb köhne eğer & 1 & 5 \\
\hline 203 & Simlüce köhne eğer & 1 & 23,5 \\
\hline 204 & Köhne kapu perdesi & 5 & 4 \\
\hline 205 & $\begin{array}{l}\text { Fağfûrî köhne buhurdân } 1 \text { adet, } \\
\text { Frengi kilid } 7 \text { adet }\end{array}$ & & 3,5 \\
\hline 206 & Sağîr Hindî çekmece & 1 & 27,5 \\
\hline 207 & Hindî sağîr beştahta devât & 2 & 33 \\
\hline 208 & Sarma tüfenk & 18 & 24 \\
\hline 209 & Çizme & 4 çift & 4 \\
\hline 210 & Çit sadr şiltesi & 4 & 11 \\
\hline
\end{tabular}




\begin{tabular}{|c|l|c|c|}
\hline 211 & Bir miktar sîm kabara & & 15 \\
\hline 212 & Kurâda tüfenk & 64 & 111 \\
\hline 213 & Trabzon keteni & 33 top & 194,5 \\
\hline 214 & Def'a kurâda tüfenk & 54 & 75 \\
\hline 215 & Köhne ve çürük çadırlar & & 100 \\
\hline 216 & Cevâri & 6 re’s $^{\prime}$ & 900 \\
\hline 217 & Gürcü gulâm & 2 re’s & 300 \\
\hline 218 & Uşâkî müsta'mel haliçe & 3 & 35 \\
\hline 219 & Medrese kurbunda vaki' dükkân & 16 bâb & \\
\hline 220 & Hâric şehirde harâbe değirmen & 2 & \\
\hline 221 & $\begin{array}{l}\text { Halilü'r-rahmân kurbunda (.....) } \\
\text { dükkân }\end{array}$ & 15 bâb & \\
\hline 222 & Arsa-i hale kit‘a & 1 & \\
\hline \multicolumn{2}{|l}{ Kıymet 850 kuruş }
\end{tabular}

Akar-i mezkûr emr ü fermân buyrulduğu üzere Medîne-i Ruha'da ve ba'dehû Haleb'de müzâyede olduktan sonra ba'de inkıtâu'r-rağbet müteveffâ-yı müşârun ileyhin kerîmesi Rahme Hanım üzerinde karârdâde ve fürûht olunmuştur.

Müteveffâ-yı müşârun ileyhin damadı Süleyman'ın ve hazînedârı Selim'in eşyâlarından hâlâ Rakka vâlisi vezîr-i mükerrem devletlü Mustafa Paşa hazretleri kendüleri için alıkoyup kapucubaşı mumâ-ileyh yediyle bahâların gönderdiği eşyânın defteridir ki vech-i âtî zikr olunur.

\begin{tabular}{|c|l|c|c|}
\hline S.No & Muhallefât & Adet/Miktar & $\begin{array}{c}\text { Kıymet } \\
\text { (Akçe) }\end{array}$ \\
\hline 1 & Nal ve mıh kem & 1200 & 240 \\
\hline 2 & Müsta'mel Bağdâdî kilim & 5 & 75 \\
\hline 3 & Köhne çuka mak'ad & 5 & 15 \\
\hline 4 & Köhne döşeme kadife yasdık & 30 çift & 60 \\
\hline 5 & Kurâda evânî nühâs & 515,5 kıyye & 430 \\
\hline 6 & Fağfûrî kâse ve tabak & & 150 \\
\hline 7 & Gürcü gulâm fî 90 akçe & 12 re's & 1080 \\
\hline 8 & Def'a gulâm fî 80 akçe & 14 re's & 1120 \\
\hline 9 & $\begin{array}{l}\text { Fransız çukası fî 210 akçe } \\
\text { (Damad Süleyman'ındır) }\end{array}$ & 56 zir'a & 130,5 \\
\hline
\end{tabular}




\begin{tabular}{|c|l|c|c|}
\hline 10 & $\begin{array}{l}\text { Larca çuka fî } 200 \text { akçe (bu } \\
\text { dahi) }\end{array}$ & 144 zir'a & 240 \\
\hline 11 & $\begin{array}{l}\text { Londra çuka Fî 150 akçe (bu } \\
\text { dahi) }\end{array}$ & 128 zir’a & 160 \\
\hline 12 & $\begin{array}{l}\text { Yeşimi top fî 150 akçe (bu } \\
\text { dahi) }\end{array}$ & 50 & 62,5 \\
\hline 13 & $\begin{array}{l}\text { Darâyî top 17,5 adet fî 12 } \\
\text { akçe (bu dahi) }\end{array}$ & 581,5 zir'a & 58 \\
\hline 14 & $\begin{array}{l}\text { Halebî camfes top 5 adet fî } \\
\text { 100 akçe (bu dahi) }\end{array}$ & 199,5 zir’a & $\begin{array}{c}166 \text { akçe } 1 \\
\text { rubu' }\end{array}$ \\
\hline 15 & $\begin{array}{l}\text { Halebî keremsût fî 500 akçe } \\
\text { (bu dahi) }\end{array}$ & 11 taka & 45,5 \\
\hline 16 & Zırh (Hazînedâr Selim'in) & 2 & 45 \\
\hline 17 & Kolçak & 1 & 2,5 \\
\hline
\end{tabular}

Müteveffâ-yı müşârun ileyhin fürûht olunan eşyâsı bahâsıdır.

Yekûn. 20.803 kuruş 1 rubu'. Yalnız yirmi bin sekiz yüz üç kuruş bir rubu'dur.

(4) Müteveffâ-yı müşârun ileyhin Ruha'da hazînesinde mevcûd bulunup hâlâ Rakka vâlisi devletlü Mustafa Paşa hazretlerinin ma'rifetiyle ve ma'rifet-i şer'le mumâ-ileyhe kapucubaşının ahz ve kabz ve götürüp mîr-i müşârun iley hazretlerine teslim eylediği nükûdudur.

Fındık ve zer-i mahbûb ve zincirli ve tuğralı altunları : $\quad 10.025,5$ kuruş.

Zolata

: 500 kuruş

Para ve beyaz akmişe(?) : 612 kuruş.

Yekûn(Urfa'dan gelen nukûd): 11.137,5 kuruş. Yalnız onbirbin yüz otuz yedi buçuk kuruştur.

Müteveffâ-yı müşârun ileyhin Damadı Süleyman'ın ve hazînedârı Selim'in Merc-i dâbık nâm mahalde ordusunda mevcûd bulunup Medîne-i Haleb'e nakl ve ma'rifet-i şer'le fürûht olunan emvâl ve eşyâ ve devâbb ve müvâşileri bahâlarından ve Ruha'da vesâ'ir mahallerden zuhûr eden nukûdlardan olmak üzere mukaddemâ devlet-i aliyyeye gönderdiği mümzî ve mahtûm fürûht defteri mûcebince ba'de'l-masârıf

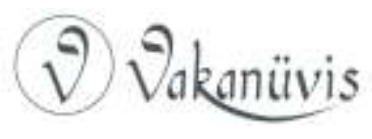


ve'l-ihracât mîr-i müşârun ileyh hazretlerinde bâkî kalan akçedir. 90.900 kuruş. Yalnız doksan bin dokuz yüz kuruştur.

Müteveffâ-yı müşârun ileyhin nukûdu ve fürûht olunan eşyâ bahâsı.

Cem‘a yekûn. 122.895,5 kuruş 1 rubu. Yalnız yüz yirmi iki bin sekiz yüz doksan beş buçuk kuruş bir rubudur.

Müteveffâ-yı müşârun ileyhin damadı Süleymân'ın Ruha'da olup yine kapucubaşı mumâ-ileyh hâlâ Rakka vâlisi vezîr-i mükerrem müşârun ileyh hazretlerinin ma'rifetleri ve ma'rifet-i şer'le Ruha'da tahrîr ve defter ve mumzî ve mahtûm defteriyle Haleb'e getürüp sa'âdetlü mîr-i müşârun ileyh hazretlerine teslîm ve mîr-i müşârun ileyh hazretleri Haleb'de ma'rifet-i şer' ve cümle ma'rifetiyle fürûht eyledikleri emvâl ve eşyâsının defteridir ki zikr olunur.

\begin{tabular}{|c|l|c|c|}
\hline S.No & Muhallefât & $\begin{array}{c}\text { Adet/ } \\
\text { Miktar }\end{array}$ & $\begin{array}{c}\text { Kıymet } \\
\text { (Akçe) }\end{array}$ \\
\hline 1 & Altun halhâl & 1 & 245 \\
\hline 2 & Altun bilezik & 1 & 155 \\
\hline 3 & Altun sağîr kuşak & 1 & 160 \\
\hline 4 & Altunluca sağîr (.....) & 1 & 28 \\
\hline 5 & Çuka seccâde 1 adet, Bağdâdî haşe 1 adet & & 12 \\
\hline 6 & Sîmlü kılıç & 1 & 32 \\
\hline 7 & Lahorî şâl & 1 & 8 \\
\hline 8 & Köhne keremsût kaftân & 4 & 21 \\
\hline 9 & Köhne kutnî kaftân & 2 & 12 \\
\hline 10 & Nühâs buhurdân & 1 & 3 \\
\hline 11 & Köhne bildâr entari & 5 & 22 \\
\hline 12 & Köhne Mardin haşe 1, halı seccâde 1 & & 18 \\
\hline 13 & Köhne Londra mak'ad & 2 & 11 \\
\hline 14 & Şâlı̂ sof 4 top, çakşılık 3 adet & & 65 \\
\hline 15 & Mevcli sof donluk 2, Lahorî şâl 1 adet & & 240 \\
\hline & Kerrâke harcî 2, (......) halı 3, poturdar 4 & & 60 \\
\hline 16 & adet & & \\
\hline 17 & Haleb bildârı 1 taka, Frengi camfes 11 taka & & 75 \\
\hline 18 & Telli Halebî hatâyî donluk & 2 & 24 \\
\hline 19 & Şam keremsûtı & 6 taka & 36 \\
\hline 20 & (yırtık) & & \\
\hline
\end{tabular}




\begin{tabular}{|c|c|c|c|}
\hline 21 & Musul bezi & 1 top & 5 \\
\hline 22 & Kerrâke harcî & 1 & 4 \\
\hline 23 & Beyaz bez donluk & 1 & 6,5 \\
\hline 24 & $\begin{array}{l}\text { Bir miktar kesme sacağı ve bükme elvân } \\
\text { ibrişim }\end{array}$ & & 46 \\
\hline 25 & Kemayâr sîm rikâb & 3 çift & 210 \\
\hline 26 & Müteârif destâr & $\begin{array}{c}24 \\
\text { taka }\end{array}$ & 96 \\
\hline 27 & Keten 1 top, köhne seccâde 1 adet & & 8,5 \\
\hline 28 & $\begin{array}{l}\text { Köhne kahve peşkiri } 8 \text { adet, Bağdâdî } \\
\text { köhne aba } 2\end{array}$ & & 39 \\
\hline 29 & Köhne kesme & 3 & 66 \\
\hline 30 & Halebî kutnî & 2 taka & 10 \\
\hline 31 & Köhne sûzenî mak'ad & 1 & 5 \\
\hline 32 & Köhne kaneviz aba & 1 & 5 \\
\hline 33 & $\begin{array}{l}\text { Elvân Fransız çuka donluk 5, çakşırlık } 1 \\
\text { adet }\end{array}$ & & 55 \\
\hline 34 & $\begin{array}{l}\text { Müsta'mel yedek örtüsü } 1 \text { adet, Mardin } \\
\text { köhne mak'adi } 1 \text { adet }\end{array}$ & & 12 \\
\hline 35 & $\begin{array}{l}\text { Köhne haşe } 2 \text { adet, kesme } 3 \text {, bayrak } 1 \\
\text { adet }\end{array}$ & & 38 \\
\hline 36 & $\begin{array}{l}\text { Mısır mahramesi } 1 \text { adet, keten } 9 \text { top, } \\
\text { Mardin kutası } 1\end{array}$ & & 55 \\
\hline 37 & Köhne kemerbend şâl & 2 & 21 \\
\hline 38 & Köhne Mardin kesmesi & 3 & 41 \\
\hline 39 & Yağlık & 15 & 11 \\
\hline 40 & Sîmlüce hançer 2 , bıçak 1 & & 28 \\
\hline 41 & Al fes 9, ağaç tesbîh 2 , sakal tarağı 2 & & 14,5 \\
\hline 42 & Sîm sağîr kuşak 3 parça, bazübend 1 & & 18 \\
\hline 43 & $\begin{array}{l}\text { Acem zerbefti cebken } 1 \text { adet, Mardin } \\
\text { peştamal } 5 \text { adet }\end{array}$ & & 25 \\
\hline 44 & Kalemkârî hılt 3, beyaz Halebî kuşak 1 & & 15 \\
\hline 45 & $\begin{array}{l}\text { Köhne Bağdat ve Mardin kesmesi } 3 \text { adet, } \\
\text { köhne haşe } 2 \text { adet, Mevc yemenî } 1 \text { top }\end{array}$ & & 75 \\
\hline 46 & Haleb merresi & 3 & 9 \\
\hline 47 & Müsta'mel çâr ve kemerbend ve köhne şâl & 16 & 210 \\
\hline
\end{tabular}




\begin{tabular}{|c|c|c|c|}
\hline 48 & Şâlî sof donluk & 3 & 45 \\
\hline 49 & Mardin peşkiri & 4 & 21,5 \\
\hline 50 & İşleme sâde havlu 14, beyaz mahreme 4 & & 58 \\
\hline 51 & $\begin{array}{l}\text { Çakmaklı destar } 18 \text { taka, Mütearaf destar } \\
1\end{array}$ & & 162 \\
\hline 52 & Meles gömlek 12, don 12, uçkur 18 & & 65 \\
\hline 53 & Yağlık me’a yemeni 3, tütün kesesi 3 & & 53 \\
\hline 54 & Tesbîh harcî & 1 & 2 \\
\hline 55 & Üstlük 1 adet, dülbend 2 parça & & 12 \\
\hline 56 & Çizme ve mest pâbuç & 11 çift & 12 \\
\hline 57 & Sağîr kemer raht & 1 & 130 \\
\hline 58 & Beyaz peçeli kemer raht & 1 & 136 \\
\hline 59 & Yaldızlı sîm debbûs & 1 & 18 \\
\hline 60 & Köhne çuka biniş & 1 & 6 \\
\hline 61 & Sîm bayrak topu & 1 & 8,5 \\
\hline 62 & $\begin{array}{l}\text { Londra kaba aba } 17 \text { adet, kaneviz aba } 4 \\
\text { adet }\end{array}$ & & 28 \\
\hline 63 & Köhne zerbeft kesme 1, pencere perdesi 1 & & 18 \\
\hline 64 & Bağdâdî ve barak kilimi & 2 & 22 \\
\hline 65 & $\begin{array}{l}\text { Sîm sağîr buhurdân 1, sîm kılabdân 1, sîm } \\
\text { buhurdân siperi } 1\end{array}$ & & 48 \\
\hline 66 & Londra çuka donluk & 3 & 22 \\
\hline 67 & Simlüce eğer 1 adet, Ayntâb eğeri 4 & & 55 \\
\hline 68 & Simlü gaddâre & & 31 \\
\hline 69 & Sîm zarf 11, kahve ibriği 1 & & 18 \\
\hline 70 & Def'a fes 17 , dizgin 1 adet & & $\begin{array}{c}18 \\
\text { akçe } 1 \\
\text { rubu' }\end{array}$ \\
\hline 71 & Yeşil çukaya kaplu köhne karsak kürk & 1 & 24 \\
\hline 72 & Neftî çukaya kaplu köhne nâfe kürk & 1 & 24 \\
\hline 73 & Çukaya kaplu köhne kakum kürk & 1 & 18 \\
\hline 74 & Sarı çukaya kaplu köhne karsak kürk & 1 & 18 \\
\hline 75 & Köhne sincâb beden kürk & 1 & 12 \\
\hline 76 & Şâle kaplu köhne sincâb kürk & 1 & 18 \\
\hline 77 & Yavru kakum & $\begin{array}{c}3 \\
\text { tahta }\end{array}$ & 85 \\
\hline
\end{tabular}




\begin{tabular}{|c|c|c|c|}
\hline 78 & $\begin{array}{l}\text { Kırmızı şâlî biniş } 2 \text { adet, köhne ihram, } 1 \\
\text { adet }\end{array}$ & & 26 \\
\hline 79 & Anadolu nâfesi tahta & 2 & 21 \\
\hline 80 & Elvân fransız çukası & 12 zira & 31 \\
\hline 81 & $\begin{array}{l}\text { Köhne keremsûta kaplu semûr bacesi } \\
\text { beden kürk }\end{array}$ & 1 & 68 \\
\hline 82 & $\begin{array}{l}\text { Angurî çukaya kaplu semmûr köhne } \\
\text { kontuş kürk }\end{array}$ & 1 & 95 \\
\hline 83 & $\begin{array}{l}\text { Gül penbe çukaya kaplu köhne semmûr } \\
\text { bâcesi biniş kürk }\end{array}$ & 1 & 54 \\
\hline 84 & Kırmızı çukaya kaplu köhne mak’ad & 3 & $\begin{array}{c}12 \\
\text { akçe } 1 \\
\text { rubu' }\end{array}$ \\
\hline 85 & $\begin{array}{l}\text { Kırmızı çukaya kaplu köhne beyaz tilki } \\
\text { kontuş kürk }\end{array}$ & 1 & 62 \\
\hline 86 & $\begin{array}{l}\text { Köhne kürk } 1 \text { adet, köhne sof kerrâke } 1 \\
\text { adet }\end{array}$ & & 22 \\
\hline 87 & Köhne şâl biniş & 3 & 18 \\
\hline 88 & $\begin{array}{l}\text { Köhne sâye çuka } 2 \text { zira, köhne ihrâm } 2 \\
\text { adet }\end{array}$ & & 18 \\
\hline 89 & Köhne Bağdâdî aba & 2 & 10 \\
\hline 90 & $\begin{array}{l}\text { Köhne sof seccâde } 1 \text { adet, halı seccâde } 1 \text {, } \\
\text { çuka seccâde } 5 \text { adet }\end{array}$ & & 35 \\
\hline 91 & $\begin{array}{l}\text { Köhne şayak mak'ad } 3 \text { adet, köhne yasdık } \\
13 \text { çift }\end{array}$ & & 48,5 \\
\hline 92 & Sîm sağîr çapkun rahtı & 1 & 57 \\
\hline 93 & $\begin{array}{l}\text { İşleme köhne kesme } 1 \text { adet, köhne kadife } \\
\text { at gömleği } 1 \text { adet }\end{array}$ & & 28 \\
\hline 94 & Köhne fener & 1 & 1,5 \\
\hline 95 & Sîm sağîr bıçak & 1 & 11 \\
\hline 96 & Fağfûrî tabak 5, kâse 1, fincân 10 adet & & 11 \\
\hline 97 & Kahve & $\begin{array}{c}372 \\
\text { kıyye }\end{array}$ & 744 \\
\hline 98 & Deve mehâr & 14 & 950 \\
\hline 99 & Amelmande katır & 14 & 372 \\
\hline 100 & Amelmande at ve kısrak ve beygir & 14 & 230 \\
\hline
\end{tabular}




\begin{tabular}{|l|l|c|c|}
\hline 101 & Dahiliye ve hariciye kebîr hânesi * & 1 bâb & \\
\hline 102 & Karapınar nâm mahalde bahçe & 1 & 1000 \\
\hline
\end{tabular}

* Mezkûr hâne ve bahçe emr ü fermân buyrulduğu üzere Medîne-i Ruha'da ve ba'dehû Haleb'de müzâyede olduktan sonra ba'de inkıtâ"rrağabat müteveffâ-yı müşârûn ileyhin hemşiresi Elif hanım üzerinde karâr-dâde ve fürûht olunmuştur.

Merkûm Süleyman'ın füruht olunan eşyâ bahâsıdır.

Yekûn 7.290,5 kuruş. Yalnız yedi bin iki yüz doksan buçuk kuruştur.

Merkûm damad Süleymân'ın Urfa'dan mumâ-ileyh kapucubaşı Hasan Ağa yediyle gelen nükûdudır.

Bezistan kethüdâsı Molla Halil yedinde çuka akçesi : : 1.728 kuruş

Kuyumcubaşıda olan akçesi

:426 kuruş

Hort oğlunda olan akçesi $: 200$ kurus

Yekûn

:2.354 kuruş. Yalnız iki bin üç yüz elli dört kuruştur.

Mezkûr damad Süleyman'ın Bağdâdi'l-aslü's-seyyîd Yunûs'dan matlûbu olan 100.000 kuruştan bi'd-def'ât kendüye teslîm eyledikten gayri sahhü'l-bâki zimmetinde kalup emr ü fermân buyrulduğu üzere mîr-i müşârun ileyh hazretleri cânib-i mîrî için tahsîl ve kabz eylediği akçedir. 55.765 kuruş. Yalnız elli beş bin sekiz yüz altmış beş kuruştur.

Merkûm Süleyman'ın fürûht olunan eşyâ bahâsı ve nükûdu.

Yekûn: 65.509 kuruş. Yalnız altmış beş bin beş yüz dokuz kuruştur.

Müteveffâ-yı müşârun ileyhin hazinedârı Selim'in Ruha'da olup yine kapucubaşı mûmâ-ileyh hâlâ Rakka vâlisi vezîr-i mükerrem devletlü Mustafa Paşa hazretlerinin ma'rifetleri ve ma'rifet-i şer'le Ruha'da tahrîr ve defter ve mumzî ve mahtûm defteriyle Haleb'e getürüp sa'âdetlü mîr-i müşârun ileyh hazrelerine teslîm ve mîr-i müşârun ileyh hazretleri ma'rifet-i şer'le fürûht eyledikleri emvâl ve eşyâsının defteridir ki bervech-i âtî müferdâtıyla zikr olunur.

\begin{tabular}{|c|l|c|c|}
\hline S.No & Muhallefât & $\begin{array}{c}\text { Adet/ } \\
\text { Miktar }\end{array}$ & Kıymet(Akçe) \\
\hline 1 & Mushaf-ı Şerîf & 3 cild & 36 \\
\hline 2 & En`am-i Şerîf & 1 cild & 2,5 \\
\hline 3 & Muhammediye & 1 & 5 \\
\hline
\end{tabular}




\begin{tabular}{|c|c|c|c|}
\hline 4 & Mecmû'a & 1 & 1,5 \\
\hline 5 & Karsak nâfesi kürk & 5 tahta & 85 \\
\hline 6 & $\begin{array}{l}\text { Lahorî şâle kaplu köhne semûr } \\
\text { bâcesi beden kürk }\end{array}$ & 1 & 75 \\
\hline 7 & $\begin{array}{l}\text { Mâi çukaya kaplu cild kafa } \\
\text { kontuş kürk }\end{array}$ & 1 & 86 \\
\hline 8 & $\begin{array}{l}\text { Kırmızı keremsûta kaplu köhne } \\
\text { vaşak beden kürk }\end{array}$ & 1 & 45 \\
\hline 9 & $\begin{array}{l}\text { Bâdzehr çukaya kaplu köhne } \\
\text { vaşak kürk }\end{array}$ & 1 & 65 \\
\hline 10 & $\begin{array}{l}\text { Mor çukaya kaplu köhne ser } \\
\text { sincâb kürk }\end{array}$ & 1 & 66 \\
\hline 11 & Sincâb kürk parça & 1 & 8 \\
\hline 12 & $\begin{array}{l}\text { Kırmızı keremsûta kaplu köhne } \\
\text { kakum cübbe kürk }\end{array}$ & 1 & 45 \\
\hline 13 & Fransız çukası donluk & 2 & 22 \\
\hline 14 & $\begin{array}{l}\text { Köhne sâye yağmurluk 2, başlık } \\
1 \text { adet }\end{array}$ & & 66 \\
\hline 15 & $\begin{array}{l}\text { Sof kerrâke } 1 \text { adet, silâh abası, } 1 \\
\text { adet }\end{array}$ & & 25 \\
\hline 16 & $\begin{array}{l}\text { Sîm sağîr buhurdân } 4 \text { adet, } \\
\text { kılabdân } 3\end{array}$ & & 175 \\
\hline 17 & $\begin{array}{l}\text { Sîm hamâ'il } 1 \text { adet, maşraba } 1 \\
\text { adet, kahve ibriği } 1\end{array}$ & & 58 \\
\hline 18 & $\begin{array}{l}\text { Sîm tabak } 1 \text { adet, zarf } 1 \text { adet, } \\
\text { tütün tablası } 2\end{array}$ & & 22 \\
\hline 19 & Sîm reşme 1 adet, debbûs 1 adet & & 35 \\
\hline 20 & $\begin{array}{l}\text { Tabkur } 1 \text { adet, dizgin } 2 \text { adet, } \\
\text { maric } 5 \text { adet }\end{array}$ & & 5 \\
\hline 21 & Sağîrca zümrüd taşı & 2 & 3,5 \\
\hline 22 & $\begin{array}{l}\text { Kerrâke harcî } 1 \text { adet, bıçak harcî } \\
1 \text { adet, sadef kaşık } 1\end{array}$ & & 11 \\
\hline 23 & Sîm ince kemer raht me’a reşme & 1 & 65 \\
\hline 24 & $\begin{array}{l}\text { Yaldızlı sağîr kemer raht me‘a } \\
\text { reşme }\end{array}$ & 1 & 86 \\
\hline 25 & Simlü debbûs & 6 & 95 \\
\hline
\end{tabular}




\begin{tabular}{|c|c|c|c|}
\hline 26 & Yaldızlı Acem baltası & 1 & 42 \\
\hline 27 & Sîm ince kısrak rahtı & 1 & 48 \\
\hline 28 & $\begin{array}{l}\text { Sîm sağîr haydarî raht me‘a } \\
\text { reşme }\end{array}$ & 1 & 62 \\
\hline 29 & $\begin{array}{l}\text { Siyâh kabzalı gaddâre } 2 \text { adet, } \\
\text { sîm haydarisi sâde başlık } 1 \text { adet }\end{array}$ & & 35 \\
\hline 30 & $\begin{array}{l}\text { Sâde kın gaddâre } 1 \text { adet, piştov } \\
\text { çift }\end{array}$ & 2 & 32 \\
\hline 31 & Simlüce piştov kubûrî & 1 & 12 \\
\hline 32 & $\begin{array}{l}\text { Çıfıt işi sağîr piştov kubûrî } 1 \\
\text { adet, küçük piştov kubûrî } 1 \text { adet }\end{array}$ & & 35 \\
\hline 33 & Anber 1 parça fî 3,5 dirhem & $\begin{array}{c}15,5 \\
\text { miskâl }\end{array}$ & 50,5 \\
\hline 34 & Sîm kabaraliçe mum sofrası & 2 & 48 \\
\hline 35 & Telli Acem zerbefti & 1 parça & 3 \\
\hline 36 & $\begin{array}{l}\text { Beyaz simlüce kılıç } 1 \text { adet, } \\
\text { Dımışkî kılıç } 1 \text { adet }\end{array}$ & & 35 \\
\hline 37 & Simlü kılıç bendi & 1 & 16 \\
\hline 38 & Sîmlüce Aydın bıçağı & 1 & 26 \\
\hline 39 & Sadefli ayna & 1 & 8 \\
\hline 40 & Bağdâdî sâde kadıfe & 12 çift & 84 \\
\hline 41 & Cedîd Bursa yasdık & 12 çift & 200 \\
\hline 42 & Köhen Bursa ve Mardin yasdığı & 19 çift & 28 \\
\hline 43 & $\begin{array}{l}\text { Deve keçesi } 15 \text { adet, çuval } 10 \\
\text { adet, sâde halı } 1\end{array}$ & & 18 \\
\hline 44 & Köhne halı 1 adet, at çulu 2 adet & & 13 \\
\hline 45 & Uşâkî ve Türkmen kilimi & 10 & 30 \\
\hline 46 & $\begin{array}{l}\text { Köhne câcim } 1 \text { adet, köhne } \\
\text { harar } 2 \text { adet }\end{array}$ & & 3,5 \\
\hline 47 & Kaval tüfenk & 10 & 95 \\
\hline 48 & $\begin{array}{l}\text { Müsta'mel orta halı } 1 \text { adet, } \\
\text { barak kilimi } 15\end{array}$ & & 32 \\
\hline 49 & Acem zerbefti & 28 parça & 225 \\
\hline 50 & Acem kutnî & 4 taka & 18 \\
\hline 51 & $\begin{array}{l}\text { Müsta'mel Mardin peşkiri } 2 \\
\text { adet, Trabzon bezi } 4 \text { top }\end{array}$ & & 28 \\
\hline
\end{tabular}




\begin{tabular}{|c|c|c|c|}
\hline 52 & Şâli sof donluk 8, çakşırlık 6 adet & & 135 \\
\hline 53 & Acem kuşağı 2 adet, Lahorî şâl 3 & & 41,5 \\
\hline 54 & Kesme saçağı & 3 & 15 \\
\hline 55 & $\begin{array}{l}\text { Köhne işleme hamam rahtı } 1 \\
\text { adet, işleme havlu } 7 \text { adet, şerbet } \\
\text { mahremesi } 2\end{array}$ & & 28 \\
\hline 56 & Köhne sûzenî mak'ad & 5 & 18 \\
\hline 57 & Sîmlüce şamdân sofrası & 1 & 15 \\
\hline 58 & Güderi dizgin & 2 & 1,5 \\
\hline 59 & $\begin{array}{l}\text { Bağdâdî aba } 1 \text { adet, kemhâ } 1 \\
\text { adet }\end{array}$ & 3 parça & 25 \\
\hline 60 & Acem dibâsı & & \\
\hline 61 & $\begin{array}{l}\text { Müsta'mel Mardin peşkiri } 2 \\
\text { adet, kahve kutusu } 3 \text { adet }\end{array}$ & & 18 \\
\hline 62 & $\begin{array}{l}\text { Sağîr ayna } 1 \text { adet, peştamal } 1 \\
\text { adet, Bağdâdî kaneviz } 5 \text { adet }\end{array}$ & & 13 \\
\hline 63 & Lezgi vezne 1 , sîm çelenk 1 adet & & 7,5 \\
\hline 64 & $\begin{array}{l}\text { Sîm hançer } 1 \text { adet, bıçak } 3 \text { adet, } \\
\text { Şam bıçağı } 1 \text { adet }\end{array}$ & & 22 \\
\hline 65 & Nîm zerbefti & 216 & \\
\hline 66 & $\begin{array}{l}\text { Mardinkârî köhne haşe 3, } \\
\text { Bağdadî aba } 3\end{array}$ & & 55 \\
\hline 67 & $\begin{array}{l}\text { Maric } 1 \text { adet, tabkur } 1 \text { adet, } \\
\text { eldiven } 3\end{array}$ & & 6 \\
\hline 68 & Sahan bezi & 3 top & 16 \\
\hline 69 & Hilâli & 1 top & 8 \\
\hline 70 & $\begin{array}{l}\text { Halebî keremsût } 2 \text { taka, yeşimi } \\
\text { çitâre } 1 \text { adet }\end{array}$ & & 21 \\
\hline 71 & $\begin{array}{l}\text { Bendî destâr } 1 \text { taka, müteârif } \\
\text { destâr } 3 \text { taka }\end{array}$ & & 50 \\
\hline 72 & Halebî yeşimi & 1 taka & 2,5 \\
\hline 73 & $\begin{array}{l}\text { Halep alacası } 1 \text { taka, sarık örtüsü } \\
1 \text { adet }\end{array}$ & & 10 \\
\hline 74 & Gezi keremsût & 1 taka & 7 \\
\hline 75 & Sîm sağîr leğen me‘a ibrik & 1 & 122 \\
\hline
\end{tabular}




\begin{tabular}{|c|c|c|c|}
\hline 76 & $\begin{array}{l}\text { İnce zencîr kısrak rahtı me‘a } \\
\text { başlık }\end{array}$ & 1 & 41 \\
\hline 77 & Basmalı altun saat & 1 & 50 \\
\hline 78 & Zarfsız ferâde Sâde altun saat & 3 & 120 \\
\hline 79 & Köhne bağa saat & 1 & 3 \\
\hline 80 & $\begin{array}{l}\text { Sîm zarf 2, tesbîh } 2 \text { adet, sakal } \\
\text { zarfı } 4\end{array}$ & & 10 \\
\hline 81 & Bir miktar öd & & 5 \\
\hline 82 & $\begin{array}{l}\text { Taşeyn(?) sîm yüzük } 4 \text { adet, } \\
\text { köhne hançer bıçak kösteği } 3 \\
\text { adet }\end{array}$ & & 41 \\
\hline 83 & Mardinkârî peştemal 1 adet futa & 1 & 10 \\
\hline 84 & Siyâh puşî hamam rahtı & 1 & 13 \\
\hline 85 & Çît yorgan yüzü & 1 & 12,5 \\
\hline 86 & $\begin{array}{l}\text { Bursa yasdık } 6 \text { çift, Bağdaî yasdık } \\
5 \text { çift }\end{array}$ & & $\begin{array}{c}66 \text { akçe } 1 \\
\text { rubu' }\end{array}$ \\
\hline 87 & $\begin{array}{l}\text { Hamam rahtı 1, işleme uçkur } 2 \text {, } \\
\text { işleme havlu } 4\end{array}$ & & 15 \\
\hline 88 & $\begin{array}{l}\text { Mardin tütün kesesi } 1 \text { adet, } \\
\text { yağlık } 19 \text { adet }\end{array}$ & & 27,5 \\
\hline 89 & $\begin{array}{l}\text { Meles gömlek } 18 \text { adet, don } 28 \\
\text { adet }\end{array}$ & & 48 \\
\hline 90 & Bez parçası & 2 & 5 \\
\hline 91 & İşleme köhne kesme & 2 & 68 \\
\hline 92 & İşleme köhne Acem digdigi & 1 & 11 \\
\hline 93 & Müsta'mel şâl kuşâk & 11 & 128 \\
\hline 94 & Karsak nâfesi & 2 tahta & 35 \\
\hline 95 & $\begin{array}{l}\text { Şâli donluk } 1 \text { adet, çakşırlık } 3 \\
\text { adet, çuka donluk } 1 \text { adet }\end{array}$ & & 31 \\
\hline 96 & Halep keremsûti & 2 taka & 8,5 \\
\hline 97 & Kakum taklîdî biniş kürk & 1 & 7 \\
\hline 98 & $\begin{array}{l}\text { Gümüşî keremsûta kaplu semûr } \\
\text { bâcesi biniş kürk }\end{array}$ & 1 & 42 \\
\hline 99 & $\begin{array}{l}\text { Göz çukaya kaplu semûr bâcesi } \\
\text { köhne kontuş kürk }\end{array}$ & 1 & 108 \\
\hline
\end{tabular}




\begin{tabular}{|c|c|c|c|}
\hline 100 & $\begin{array}{l}\text { Kırmızı keremsûta kaplu köhne } \\
\text { semûr bâcesi beden kürk }\end{array}$ & 1 & 51 \\
\hline 101 & $\begin{array}{l}\text { Köhne Bursa yasdık } 6 \text { çift, } \\
\text { minder gılafı } 1 \text { adet }\end{array}$ & & 25 \\
\hline 102 & Keşan kutnîsi 4, Mardin kutnîsi 2 & & 21 \\
\hline 103 & Sof donluk & 1 & 16 \\
\hline 104 & Beyaz ince haydarî raht & 1 & 42,5 \\
\hline 105 & İnce yaldızı ıaydarî raht & 1 & 48 \\
\hline 106 & Bir miktar şerbet & & 6 \\
\hline 107 & Yavru kakum & 2 tahta & 45 \\
\hline 108 & $\begin{array}{l}\text { Çıfıt işi sağîr buhurdân } 1 \text {, } \\
\text { kılabdân } 1 \text { adet }\end{array}$ & & 62 \\
\hline 109 & Köhne sûzenî seccâde & 1 & 18 \\
\hline 110 & $\begin{array}{l}\text { Meles gömlek } 8 \text { adet, don } 8 \\
\text { adet, şerbet mahremesi } 2 \text { adet }\end{array}$ & & 34,5 \\
\hline 111 & $\begin{array}{l}\text { Sarık örtüsü } 2 \text { adet, kahve } \\
\text { kutusu } 1 \text { adet, tütün kesesi } 2 \\
\text { adet }\end{array}$ & & 28 \\
\hline 112 & $\begin{array}{l}\text { Kumaş parçaları } 3 \text { adet, befçe } 3 \\
\text { adet, üstlük } 2 \text { adet }\end{array}$ & & 11 \\
\hline 113 & Köhne dibâ mak'ad & 1 & 12,5 \\
\hline 114 & Destar cevzî & 1 & 21 \\
\hline 115 & Köhne nühâs fener & 1 & 2,5 \\
\hline 116 & $\begin{array}{l}\text { Yaldızlı ince kemer raht me`a } \\
\text { başlık }\end{array}$ & 2 & 163 \\
\hline 117 & Haydarî raht & 1 & 32 \\
\hline 118 & $\begin{array}{l}\text { Sîm sağîr şamdan } 2 \text { adet, sîm } \\
\text { zarf } 5 \text { adet, ma'den şamdan } 1 \\
\text { adet }\end{array}$ & & 50 \\
\hline 119 & $\begin{array}{l}\text { Sîm sağîr buhurdân } 1 \text { adet, } \\
\text { kılabdân } 1 \text { adet, kahve ibriği } 1\end{array}$ & & 53 \\
\hline 120 & Sîm sağîr kahve tepsisi & 1 & 18 \\
\hline 121 & Sâde Bağdâdî yasdık & 18 çift & 95,5 \\
\hline 122 & Köhne dibâ aba & 3 & 32 \\
\hline 123 & Köhne dibâ haşe & 2 & 10,5 \\
\hline 124 & Mızrak demiri & 1 & 1 \\
\hline
\end{tabular}




\begin{tabular}{|c|c|c|c|}
\hline 125 & $\begin{array}{l}\text { Aynalı iskemle } 1 \text { adet, köhne } \\
\text { iskemle sofrası } 1 \text { adet }\end{array}$ & & 16 \\
\hline 126 & Sakızı tütün kesesi & 5 & 15 \\
\hline 127 & Sîm tas 6 adet, zarf 28 adet & & 75 \\
\hline 128 & Sağîr altun zarf & 1 & 16 \\
\hline 129 & $\begin{array}{l}\text { Sîm buhurdân } 1 \text { adet, kılabdân } 1 \\
\text { adet, kahve ibriği } 4 \text { adet }\end{array}$ & & 72 \\
\hline 130 & $\begin{array}{l}\text { Sîm kahve tepsisi 2, sermerdân } 1 \\
\text { adet }\end{array}$ & & 33 \\
\hline 131 & Yeşim kabzalı hançer & 1 & 150 \\
\hline 132 & Çerkes bıçağı & 3 & 2,5 \\
\hline 133 & $\begin{array}{l}\text { İncilüce saat kesesi 1, peşkir } \\
\text { kese } 1 \text { adet }\end{array}$ & & 28 \\
\hline 134 & İncilüce tarak gılafı & 1 & 12 \\
\hline 135 & İşleme gılaf 2 , kaşık 4 deste & & 10 \\
\hline 136 & $\begin{array}{l}\text { Çakı ve misvak gılafı 3, saat } \\
\text { kesesi } 1\end{array}$ & & 8 \\
\hline 137 & Süleymânî kabza & 1 & 3 \\
\hline 138 & Sîm saat & 1 & 16 \\
\hline 139 & Kerrâke beftesi & 8 & 11,5 \\
\hline 140 & Bağa sağîr çekmece (yırtık) & & \\
\hline 141 & Köhne Acem keçesi & 2 & $\begin{array}{c}6 \text { akçe } 1 \\
\text { rubu' }\end{array}$ \\
\hline 142 & $\begin{array}{l}\text { Uşakî kilim } 3 \text { adet, köhne ihrâm } \\
4 \text { adet }\end{array}$ & & 31 \\
\hline 143 & Sağîr pirinç şamdan & 11 & 22 \\
\hline 144 & Nühâs mikras & 2 & 1 \\
\hline 145 & Karâda vezne & 1 & 1,5 \\
\hline 146 & $\begin{array}{l}\text { Pirinç iskemle } 2 \text { adet, nühâs } \\
\text { ferrâş } 1 \text { adet }\end{array}$ & & 11 \\
\hline 147 & $\begin{array}{l}\text { Büllur kâse } 1 \text { adet, büllûr } \\
\text { kılabdân } 1\end{array}$ & & 5 \\
\hline 148 & $\begin{array}{l}\text { Gülbe şeker tabağı } 25 \text { adet, } \\
\text { bakır kahve ibriği } 1 \text { adet }\end{array}$ & & 12 \\
\hline 149 & Sîm zarf & 6 & 13 \\
\hline
\end{tabular}




\begin{tabular}{|c|l|c|c|}
\hline 150 & $\begin{array}{l}\text { Müsta'mel sağîr kilim 1 adet, } \\
\text { seccâde 1 adet }\end{array}$ & 21 \\
\hline 151 & Tüfenk & 11 & 77 \\
\hline 152 & Gürcü gulâm benam Yusuf & 1 re's & 115 \\
\hline 153 & Def'a gulâm benâm-ı Rüstem & 1 re's & 105 \\
\hline 154 & Def'a gulâm benâm Veli & 1 re's & 95 \\
\hline 155 & Def'a gulâm benâm Sâlih & 1 re's & 90 \\
\hline 156 & Def'a gulâm benâm Kâsım & 1 re's & 85 \\
\hline 157 & Nâ-bâliğa câriye & 2 re's & 300 \\
\hline 158 & Amelmande tay ve kısrak & 3 & 4 \\
\hline
\end{tabular}

Hazînedâr-ı merkûmun fürûht olunan eşyâsı bahâsı.

Yekûn:6.350 kuruş 1 rubu'. Yalnız altı bin üç yüz elli kuruş bir rubu'dur.

Hazînedâr-ı merkûmun Ruha'da bulunup hâlâ Rakka vâlisi vezîr-i müşârun-ileyh hazretlerinin ma'rifetleri ve ma'rifet-i şer'le kapucubaşı mûmâ ileyhin ahz ve kabz ve getürüp mîr-i müşârun ileyh hazretlerine teslîm eylediği nukûdudur.

\begin{tabular}{|c|c|c|c|}
\hline $\begin{array}{c}\text { Zer-mahbûb ve } \\
\text { zincirli altun } \\
\text { 1.191,5 adet } \\
3.276,5 \text { kuruş } \\
\text { Yalnız üçbin iki yüz } \\
\text { yetmiş altı buçuk } \\
\text { kuruştur. } \\
\text { Meblağ-ı mezbûr } \\
\text { hazîne kâtibinin } \\
\text { hânesinde zuhûr } \\
\text { eden sandığında } \\
\text { çımıştır. }\end{array}$ & \multicolumn{2}{|c|}{$\begin{array}{l}\text { Arpa kâtibi Mehmed } \\
\text { Fazlı Efendi nâm } \\
\text { kimesnede olan } \\
\text { emânet nükûdu } \\
8.500 \text { kuruş. } \\
\text { Yalnız sekiz bin beş } \\
\text { yüz kuruştur. }\end{array}$} & $\begin{array}{l}\text { Hazînedâr-i } \\
\text { merkûmun Molla } \\
\text { Hüseyin yediyle } \\
\text { koyun akçesi } \\
600 \text { kuruş. } \\
\text { Yalnız altı yüz } \\
\text { kuruştur. }\end{array}$ \\
\hline \multicolumn{2}{|c|}{$\begin{array}{l}\text { Hazînedâr-ı merkûmun Bağdadi'l- } \\
\text { aslü's-seyyîd Yunus'dan matlûbu } \\
\text { olup mîr-i müşârun ileyh } \\
\text { hazretlerinin cânib-i mîrî için } \\
\text { tahsîl ve kabz eylediği akçedir. }\end{array}$} & \multicolumn{2}{|c|}{$\begin{array}{l}\text { Yine hazînedâr-ı merkûmun } \\
\text { Bağdâdi'l-asl el-Hac Mehmed } \\
\text { Hâşim nâm kimesneden } \\
\text { matlûbu olup mîr-i müşârun } \\
\text { ileyh hazretleri cânib-i mîrîi için } \\
\text { tahsîl ve kabz eylediği akçedir. }\end{array}$} \\
\hline
\end{tabular}




\begin{tabular}{|c|c|}
\hline $\begin{array}{c}10.000 \text { kuruş. Yalnız on bin } \\
\text { kuruştur. }\end{array}$ & $\begin{array}{c}3.000 \text { kuruş. Yalnız üç bin } \\
\text { kuruştur. }\end{array}$ \\
\hline
\end{tabular}

Hazinedar-ı merkûmun nukûdu.

Yekûn:35.376,5 kuruş. Yalnız otoz beş bin üç yüz yetmiş altı buçuk kuruştur.

Hazînedâr-ı merkûmun füruht olunan eşyâ bahâsı ve nukûdu.

Cem'a Yekûn:31.726,5 kuruş 1 rubu'. Yalnız otuz bir bin yedi yüz yirmi altı buçuk kuruş bir rubu'dur.

Müteveffâ-yı müşârun ileyhin damadı Süleyman'ın ve hazînedârı Selim'in fürûht olunan eşyâları bahâsı ve nukûdları.

Cemî'u'l-cem'i yekûn:

Müteveffâ-yı müşârun ileyhin nukûd ve eşyâ bahâsı: 122.895,5 kuruş 1 rubu'

Damad Süleymman'ın nükûd ve eşyâ bahâsı : 65.509,5 kuruş

Hazînedâr Selim'in nukûd ve essyâ bahâsı : $31.726,5$ kuruş 1 rubu' : 220.132 kuruş.

Min haysü'l-mecmu' yalnız iki yüz yirmi bin yüz otuz iki kuruştur.

El-masârıf ve ihracât. Minhâ.

\begin{tabular}{|c|c|c|}
\hline $\begin{array}{c}\text { Bir kıt'a sebeb-i } \\
\text { tahrîr hükmü } \\
\text { mûcebince mevâcib-i } \\
\text { yeniçeriyân-ı dergâh- } \\
\text { i alî ve muhâfaza-i } \\
\text { kal'a-i Bağdad. Fî } 1 \\
\text { Receb sene } 1157 . \\
\text { 185.236 kuruş } 16 \\
\text { para. } \\
\text { Meblağ-ı mezkûr } \\
\text { tamâmen salyâneci } \\
\text { Ahmed Çavuş Ağa'ya } \\
\text { teslîm ve sebeb-i } \\
\text { tahrîri ahz } \\
\text { olunmuştur. }\end{array}$ & $\begin{array}{c}\text { Bir kıt’a sebeb-i } \\
\text { tahrîr hükmü } \\
\text { mûcebince çuka } \\
\text { bahası yeniçeriyân-ı } \\
\text { dergâh-ı alî der- } \\
\text { muhâfaza-i kal'a-i } \\
\text { Bağdad fî } 1 \text { Receb } \\
\text { sene } 1157 . \\
9.232,5 \text { kuruş. } \\
\text { Mezkûr Ahmed } \\
\text { Çavuş Ağa'ya teslîm } \\
\text { ve sebeb-i tahrîri ahz } \\
\text { olunmuştur. }\end{array}$ & $\begin{array}{c}\text { Bir kıt'a sebeb-i } \\
\text { tahrîr hükmü } \\
\text { mûcebince lahm-ı } \\
\text { bahâ-i cebeciyân-ı } \\
\text { dergâh-o alî der- } \\
\text { muhâfaza-i kal'a-i } \\
\text { Bağdad fî } 1 \text { Receb } \\
\text { sene } 1157 . \\
1.457 \text { kuruş. } \\
\text { Tamâmen salyâneci } \\
\text { İsmâil Çavuş'a teslîm } \\
\text { ve sebeb-i tahrîri ahz } \\
\text { olunmuştur. }\end{array}$ \\
\hline
\end{tabular}




\begin{tabular}{|c|c|c|c|}
\hline $\begin{array}{l}\text { Bir kıt'a sebeb-i } \\
\text { tahrîr hükmü } \\
\text { mûcebince lahm-i } \\
\text { bahâ -i doğanciyân-ı } \\
\text { dergâh-ı ali der- } \\
\text { muhâfaza-i kal'a-i } \\
\text { Bağdad. Fî } 1 \text { Receb } \\
\text { senen } 1157 . \\
\text { 1.797,5 kuruş. } \\
\text { Tamâmen salyâneci } \\
\text { Ahmed Çavuş'a } \\
\text { teslîm ve sebeb-i } \\
\text { tahrîri ahz } \\
\text { olunmuştur. }\end{array}$ & \multicolumn{2}{|c|}{$\begin{array}{l}\text { Bir kıt'a sebeb-i } \\
\text { tahrîr hükmü } \\
\text { mûcebince lahm-i } \\
\text { bahâ-i top-i } \\
\text { arabaciyân-ı dergâh-ı } \\
\text { ali der-muhâfaza-i } \\
\text { kal'a-i Bağdad. Vâcib } \\
\text { sene } 1157 . \\
\text { 1.363,5 kuruş } 15 \\
\text { para. } \\
\text { Tamâmen salyâneci } \\
\text { Mustafa Çavuş'a } \\
\text { teslîm ve sebeb-i } \\
\text { tahrîri ahz } \\
\text { olunmuştur. }\end{array}$} & $\begin{array}{l}\text { Muteveftä-yı } \\
\text { müşârun ileyh Kilis'e } \\
\text { gelür iken Ayntâb'da } \\
\text { El-Hac Ahmed Ağa } \\
\text { yedinden ber- } \\
\text { mûceb-i temessük } \\
\text { istikrâz ve üzerine } \\
\text { sarf ettirdiği sebebi } \\
\text { ile fevtinden sonra } \\
\text { beyân edüp emvâl } \\
\text { ve eşyâsından olmak } \\
\text { üzere ber-mûceb-i } \\
\text { hüccet-i şer'iyye mîr- } \\
\text { i müşârun ileyh } \\
\text { hazretleri yedinden } \\
\text { ahz eylediği akçedir. } \\
4.000 \text { kuruş. }\end{array}$ \\
\hline \multicolumn{2}{|c|}{$\begin{array}{l}\text { Müteveffâ-yı müşârun ileyhin } \\
\text { tebâbet hizmetinde iken fevt olan } \\
\text { davudzâde Mustafa Efendi'nin } \\
\text { muhallefâtı bahâsından olmak } \\
\text { üzere vasîsi Mehmed Efendi } \\
\text { yedinden müteveffâ-yı müşârun } \\
\text { ileyh hayâtında istikrâz ve } \\
\text { umûruna sarf etmekle fevtinden } \\
\text { sonra vasi-i mezbûr beyân edüp } \\
\text { Müteveffâ-yı müşârun ileyhin } \\
\text { emvâl ve eşyâsı bahâsından } \\
\text { olmak üzere ber-mûceb-i hüccet-i } \\
\text { şer'iyye mîr-i müşârun ileyh } \\
\text { hazretleri yedinden ahz eylediği } \\
\text { akçedir. } 432,5 \text { kuruş. }\end{array}$} & \multicolumn{2}{|c|}{$\begin{array}{l}\text { Müteveffâ-yı müşârun ileyh hâl- } \\
\text { i hayâtında Es-Seyyid } \\
\text { Mustafa'nın yedinden istikrâz } \\
\text { ve ümûruna sarf etmekle } \\
\text { vefâtından sonra emvâl ve } \\
\text { eşyâsı bahâsından olmak üzere } \\
\text { mîr-i müşârun ileyh hazretleri } \\
\text { mûmâ ileyh Mustafa Bey’e edâ } \\
\text { eylediği akçedir. } \\
5.000 \text { kuruş. }\end{array}$} \\
\hline $\begin{array}{l}\text { Müteveffâ-yı } \\
\text { müşârun ileyhin } \\
\text { damadı Süleyman'ın } \\
\text { ve hazînedârı } \\
\text { Selim'in Ruha'da }\end{array}$ & \multicolumn{2}{|c|}{$\begin{array}{l}\text { Müteveffâ-yı } \\
\text { müşârun ileyhin ibkâ } \\
\text { olunan emvâl ve } \\
\text { eşyâsı emr ü fermân } \\
\text { buyrulduğu üzere }\end{array}$} & $\begin{array}{l}\text { Sâlifü’z-zikr fürûht } \\
\text { olunan eşyâdan ber- } \\
\text { mûceb-i mu'tâd } \\
\text { dellâliye ve kâtip. } \\
861 \text { kuruş } 1 \text { rubu'. }\end{array}$ \\
\hline
\end{tabular}




\begin{tabular}{|c|c|c|}
\hline $\begin{array}{c}\text { bulunan emvâl ve } \\
\text { eşyâsı haleb'e nakl }\end{array}$ & $\begin{array}{c}\text { İskenderun } \\
\text { iskelesine nakl } \\
\text { olundukta }\end{array}$ & olundukta ücret-i \\
kapucubaşı Hasan & mekkâri ve masârıf-i & \\
Ağa yediyle ücret-i & sâ'ire 325,5 kuruş. & \\
mekkâri be masârıf-ı & \\
sâ'ire ber-mûceb-i & & \\
defter mumzî ve & \\
mahtûm. & & \\
366,5 kuruş 1 rubu. & & \\
\hline
\end{tabular}

El-Masârıf ve'l-ihracât

Yekûn 210.033 kuruş. Yalnız ikiyüz on bin otuz üç kuruştur.

Müşârun ileyh hazretlerinin taht-ı yedlerinde ba'de'l-masraf ve'l-ihracât bâki kalan akçedir.

El-bâki 10.099 kuruş. Yalnız on bin doksan dokuz kuruştur.

Hurire hezâ't-defter be-ma'rifeti'l-fakîr ileyhe azze şa'nühû. Mustafa el-kâdî bi-medîneti Halebü'ş-Şehbâ. 